Maataloustieteellinen Aikakauskirja

Journal of Agricultural Science in Finland

Vol. 58: 103-141, 1986

\title{
AN ANALYTICAL AND BREEDING STUDY ON FATTY ACIDS IN SUMMER TURNIP RAPE (Brassica campestris L. var. annua)
}

Selostus: Tutkimus kevätrypsin (Brassica campestris L. var. annua) rasvahappojen analytiikasta ja jalostuksesta

INTO LAAKSO

Division of Pharmacognosy, School of Pharmacy,

University of Helsinki,

SF-00170 HELSINKI, Finland

ACADEMIC DISSERTATION

To be presented, with the permission of the

Faculty of Science of the University of Helsinki,

for public criticism in Auditorium XII

on December 3rd, 1986, at 12 o'clock. 


\section{Preface}

The present study was carried out at the Division of Pharmacognosy, School of Pharmacy, University of Helsinki, during the years 1978-86.

I owe my deepest gratitude to Professor Max von Schantz, Head of the Division, for suggesting the subject of this study, his interest and encouragement in my work and for perusing the manuscript.

I am especially grateful to Associate Professor Ratmo Hiltunen, for his innumerable advice and the support he has given me over a long period of time and his repeated encouragement to complete this study.

I am also grateful to Hankkija Plant Breeding Institute, Hyrylä, for fruitful cooperation during these years. I wish to thank Professor ERKKI KIVI, Head of the Institute, for advice concerning the manuscript. I extend special thanks to Simo HoVINEN, Lic.Agr. \& For., not only for several discussions on the area of plant breeding but also for keeping the large material included in this study under control.

I would like to thank Professor J. Johan LindBerg, Department of Wood and Polymer Chemistry, and SEPPo RÄISÄNEN, Head of the Instrument Centre of Chemistry, for providing advice and facilities in capillary column technology.

I wish to thank Professor Aarre Huhtikangas, University of Kuopio, for several fruitful discussions.

I express my appreciation to TuUlikki Seppänen, M.Sc., Jorma Kajaste, M.Sc. and Pertti Koiranen, M.Sc., for their excellent assistance in our laboratory. The work done by Ms Outi Kovanen and Ms Hannele Uusitalo at Hankkija laboratory is gratefully acknowledged.

I wish also thank my colleagues and personnel at our division. My thanks are also due to John Derome, M.Sc., who translated this thesis into English and has checked the language of the separate papers.

This study was supported by grants from the Academy of Finland, Farmasian Opettajien ja Tieteenharjoittajien Seura r.y. and Suomen Apteekkariyhdistys r.y. I am grateful to the Scientific Agricultural Society of Finland for including this study in their series of publications.

Helsinki, October 1986

Into Laakso 



\title{
An analytical and breeding study on fatty acids in summer turnip rape (Brassica campestris $\mathbf{L}$. var. annua)
}

\begin{abstract}
The fatty acid composition of the seed oil of summer turnip rape (Brassica campestris L. var. annua) was investigated by gas liquid chromatography (GLC). The reliability of conventional sampling methods in capillary GC was compared with that of the new oncolumn and PTV (programmed temperature vaporizer) techniques, with particular reference to the determination of fatty acid variation. In order to develop new, well-adapted turnip rape strains with improved oil quality, a breeding programme for a higher linoleic acid content, based on individual plant selection, was performed in 1978-85.

The results showed that the conventional sampling techniques involving sample transfer to a hot injector were very unreliable as regards precision and accuracy. This was especially the case in the determination of trace fatty acid levels. The PTV methods with splitless and solvent split mode were as precise as cold on-column injection. The PTV sampling modifications, which are all superior to classical techniques, were even more suitable for routine analyses than on-column injection, where several restrictions are met. The analytical error with PTV for most of the compounds represented less than $1 \%$ of the variation found for fatty acids within a turnip rape variety.

The breeding experiments indicated that the level of linoleic acid can be increased under open-poilinated conditions in the field without affecting the $\alpha$-linolenic acid content. The greenhouse conditions, on the other hand, were found to have a considerable environmental influence on the variation of these compounds, resulting in no response to linoleic-acid selecion. In field trials, several strains with yields comparable to the varieties commonly cultivated in Finland were selected with a higher linoleic acid content (up to $25 \%$ ). Most of them also contained no erucic acid.

The new evidence concerning its beneficial physiological effects indicate that rapeseed oil should be considered as a serious alternative among sources of essential fatty acids. Such aspects should also be taken into account in future breeding of rapeseed fatty acids.
\end{abstract}

Index words: Turnip rape, fatty acids, breeding, GLC, PTV sampling technique 


\section{List of publications}

I Hiltunen, R., Laakso, I., Hovinen, S. and Derome, J. 1982. Sampling techniques in the glass capillary gas chromatography of fatty acids of rape-seed, J. Chromatogr. 237, 41-48.

II Laakso, I., Hiltunen, R., Hovinen, S., v. Schantz, M. and Huhtikangas, A. 1982. Selection of high linoleic acid content in summer turnip rape (Brassica campestris L.). I. Variation of fatty acids in an irradiated crossing material, Acta Agrig. Scand. 32, 397-404.

III Laakso, I., Hiltunen, R., Seppänen, T. and v. Schantz, M. 1983. Relationships between some fatty acid isomers in rapeseed oil, Acta Pharm. Fenn. 92, 127-135.

IV Laakso, I., Hiltunen, R. and Hovinen, S. 1983. Selection of high linoleic acid content in summer turnip rape (Brassica campestris L.). II. Variation in linoleic acid content in successive generations, Proc. $6^{\text {th }}$ Int. Rapeseed Conf., Paris, France, C: $607-612$.

V Laakso, I. 1985. Selection of high linoleic acid content in summer turnip rape (Brassica campestris L.). III. Effects of selection on fatty acid composition, Acta Pharm. Fenn. 94, 51-57.

VI Laakso, I., Hiltunen, R., Kajaste, J. and v. Schantz, M. 1985. Single seed fatty acid analysis of rapeseed, Acta Pharm. Fenn. 94, 59-65.

VII Laakso, I., Hovinen, S. and Hiltunen, R. 1986. Selection of high linoleic acid content in summer turnip rape (Brassica campestris L. ssp. oleifera var. annua). IV. Selection of improved oil yield, Acta Agric. Scand. 36, 347-351.

In the text the papers are referred to by their Roman numerals. 


\section{Contents}

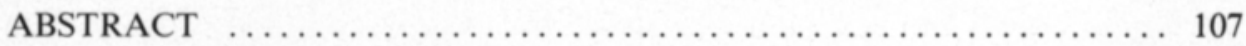

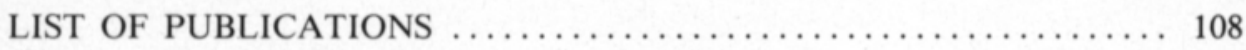

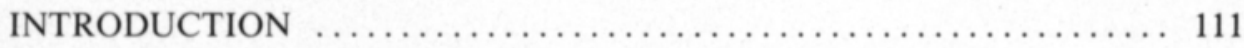

THE AIMS OF THE STUDY $\ldots \ldots \ldots \ldots \ldots \ldots \ldots \ldots \ldots \ldots \ldots \ldots \ldots \ldots \ldots \ldots \ldots \ldots, 113$

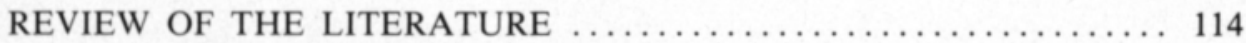

A. GAS LIQUID CHROMATOGRAPHY OF FATTY ACIDS ...... 114

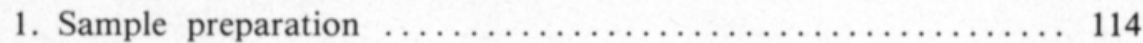

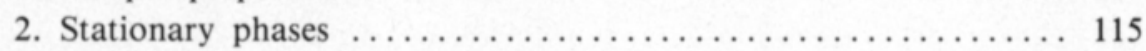

3. Conventional sampling methods $\ldots \ldots \ldots \ldots \ldots \ldots \ldots \ldots \ldots \ldots \ldots \ldots \ldots \ldots$

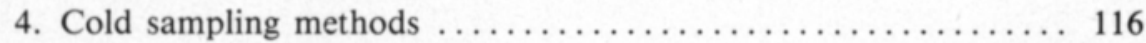

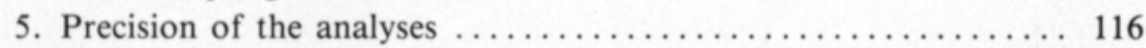

B. BREEDING FOR FATTY ACID COMPOSITION IN RAPESEED OIL 116

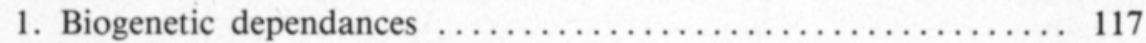

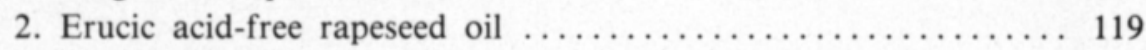

3. Breeding for polyunsaturated fatty acids $\ldots \ldots \ldots \ldots \ldots \ldots \ldots \ldots \ldots \ldots$

C. THE ROLE OF POLYUNSATURATED FATTY ACIDS IN THE DIET $\ldots \ldots \ldots \ldots \ldots \ldots \ldots \ldots \ldots \ldots \ldots \ldots \ldots \ldots \ldots \ldots \ldots \ldots \ldots \ldots \ldots \ldots \ldots \ldots, 121$

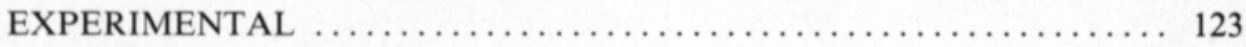

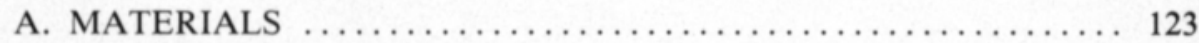

B. METHODS $\ldots \ldots \ldots \ldots \ldots \ldots \ldots \ldots \ldots \ldots \ldots \ldots \ldots \ldots \ldots \ldots \ldots \ldots \ldots \ldots \ldots \ldots \ldots, 123$

1. Analytical methods .............................. 123

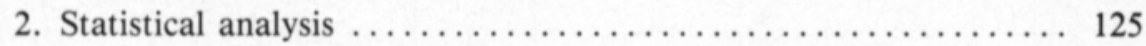

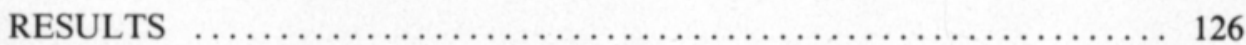

A. GAS CHROMATOGRAPHY $\ldots \ldots \ldots \ldots \ldots \ldots \ldots \ldots \ldots \ldots \ldots \ldots \ldots \ldots \ldots \ldots \ldots$

1. Conventional vs. on-column technique $\ldots \ldots \ldots \ldots \ldots \ldots \ldots \ldots \ldots \ldots \ldots$

2. Programmed temperature vaporization (PTV) techniques ...... 127

B. BREEDING EXPERIMENTS $\ldots \ldots \ldots \ldots \ldots \ldots \ldots \ldots \ldots \ldots \ldots \ldots \ldots \ldots \ldots \ldots \ldots$

1. Variation in fatty acids $\ldots \ldots \ldots \ldots \ldots \ldots \ldots \ldots \ldots \ldots \ldots \ldots \ldots \ldots \ldots \ldots \ldots, 128$

2. The long-term effects of selection $\ldots \ldots \ldots \ldots \ldots \ldots \ldots \ldots \ldots \ldots \ldots \ldots \ldots$

3. Interrelationships between fatty acids $\ldots \ldots \ldots \ldots \ldots \ldots \ldots \ldots \ldots$

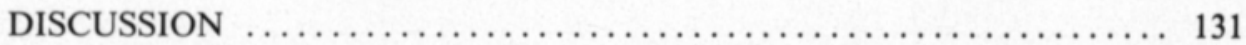

A. COMPARISON OF SAMPLING TECHNIQUES IN FATTY ACID ANALYSIS $\ldots \ldots \ldots \ldots \ldots \ldots \ldots \ldots \ldots \ldots \ldots \ldots \ldots \ldots \ldots \ldots \ldots \ldots \ldots \ldots \ldots \ldots \ldots, 131$ 
B. SELECTION FOR HIGHER LINOLEIC ACID CONTENT IN RAPESEED OIL

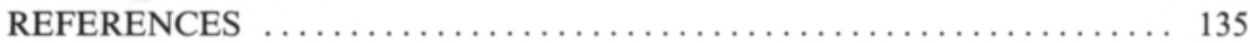

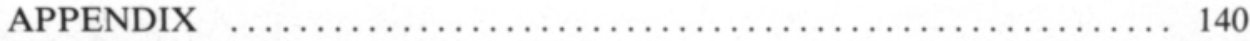

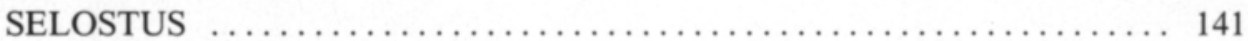




\section{Introduction}

The cultivation of oil plants as the most economic way of producing fats has considerably increased during the last decades along with the development of cultivation techniques and industrial processing know-how. Soybean holds first place among oilseeds, accounting for one third of the world's production of vegetable oil. It is followed in importance by oil palm, sunflower and rapeseed (Brassica sp.). Due to its excellent adaptability to different climatic conditions, rapeseed has enabled vegetable oil to be produced in areas ever further to the north. This expansion has been speeded up by compositional improvements achieved through intensive breeding such as elimination of erucic acid $(22: 1 \omega 9)$ from the oil, and reduction of the glucosinolate content in the meal (DowNEY 1983, Pigden 1983, Fochem 1985).

In Finland, turnip rape (Brassica campestris L.) is cultivated in the southern and central parts of the country, while rape (B. napus L.) only produces a high-quality crop in a narrow zone running along the southwestern and southern coasts. At present, summér varieties (var. annua) only are cultivated (HoviNEN 1985). Following the introduction (in 1976) of practically erucic acid-free varieties, cultivation has come under special direction of the government in order to increase selfsufficiency in domestic vegetable oil (ANON 1978, 1982). Finnish rapeseed oil is of very high quality and the norms as regards erucic acid are especially tight, since the maximum permitted level in sown seed is $0.5 \%$ (HoviNEN 1985). The oil produced has an erucic acid content clearly below the EEC's recom- mended maximum level of $5 \%$ (ANON 1980).

Elimination of erucic acid associated with a simultaneous increase in the polyunsaturated linoleic $(18: 2 \omega 6)$ and $\alpha$-linolenic $(18: 3 \omega 3)$ acid contents, has put rapeseed in a new position among sources of edible oils. These two essential components account for one third of the fatty acid content, thus making the new rapeseed oil rather competitive with many other vegetable oils. However, the content of linoleic acid is still very low compared to that of soybean or sunflower oil, for instance. Achieving a further increase in the amount of linoleic acid, which is nutritionally the most important constituent of the oil, is therefore the primary goal of breeding work (THIES 1968, Downey and McGregor 1975, RöBbeLEN 1976, JÖNSSON 1977 b).

Modification of the proportions of linoleic and $\alpha$-linolenic acids is, however, a rather laborious process due to their limited range of variation. Their inheritance is far more complex than that of erucic acid and, in addition, the variation is influenced by the environment to a considerable degree (KONDRA and Thomas 1975, BARTKOWIAK-BRODA 1983, STEFANSSON 1983). In such cases a reproducible analytical technique is of decisive importance in separating the effects of genetical properties and the environment.

Gas liquid chromatography (GLC) has been the main analytical method used for studying fatty acids ever since the time it was first developed. It has not only shown that the group of naturally occurring fats is much more diverse than was first suspected, but has also 
played an important role in breeding work on rapeseed fatty acids. The capillary technique has increasingly superceded the use of packed columns, and new stationary phases have made it possible to analyse ever more complicated mixtures of isomers (LIE KEN JIE 1980). The present-day technique is called with good reason high resolution gas chromatography. It is usually coupled with the latest applications of sampling methods. On-column and programmed temperature vaporizer (PTV) injection systems, which have enabled considerable strides to be made in quantification, have been developed alongside the traditional GC techniques (SchombURG et al. 1977, GroB and Grob 1978, Poy et al. 1981).

The so-called half-seed technique is considered to be the best tool in breeding for higher linoleic acid content in rapeseed oil. Crosses can be made on plants with known chemotypes, and the greenhouse offers better controlled conditions (JöNSSON 1977 b). However, no studies have been reported on the longterm effects of linoleic acid selection based on individual plants grown under openpollinated field conditions. When carrying out breeding trials over a number of years, optimization of the analytical techniques is therefore a basic prerequisite in elucidating the effects of selection. 


\section{The aims of the study}

The aims of this study were:

1. To study the reliability of the traditional gas chromatographic methods in fattyacid analysis, and to optimize, using the latest injection technique, the GC method best suited for the breeding work in question.
2. To study the variation of fatty acids in the seed oil of summer turnip rape and to increase the linoleic acid content through individual plant selection.

3. To study the effects of selection on the fatty-acid composition and the yield of the breeding lines. 


\section{Review of the literature}

\section{A. Gas liquid chromatography of fatty acids}

Gas chromatography is the most suitable of the methods applied in the quantitative and qualitative analysis of fatty acids. Owing to its speed, sensitivity and accuracy it has largely replaced traditional techniques such as paper and column chromatography (THIELE 1979). A decisive improvement in gas chromatographic separation has been achieved by employing glass and silica capillary columns, whose thermal stability has been further improved by the development of deactivation and phase techniques (e.g. chemical bonding). These topics have been dealt with extensively in the review articles of e.g. LEE and WRIGHT (1980) and HAKEN (1984). The column preparation methods and modifications in fattyacid analysis have been described in a large number of studies (SCHOMBURG and HUSMANN 1975, Grob and Grob 1976, Sisfontes et al. 1981, Arrendale et al. 1983, LercKer 1983, BoHov et al. 1984, GolovnYA et al. 1984).

Detection of fatty acids in GLC is usually done by a flame ionization detector (FID), as well as mass spectrometrically using a massselective detector (MS). The differences in the FID responses of e.g. palmitic, oleic, linoleic and $\alpha$-linolenic acids, are insignificant with respect to stearic acid $(\mathrm{F}=1.00-1.01)(\mathrm{BA}$. DINGS and de JoNG 1983), although with longer carbon chain compounds and higher degrees of unsaturation the differences may become considerable $(22: 1 \omega 9, \quad \mathrm{~F}=1.23$; $22: 6 \omega 3, \mathrm{~F}=1.59$ ) (Slover and Lanza 1979). However, the values are specific for each instrument and are affected to some extent by e.g. the "dead volumes" of the detector and the flow ratios of the gases (Y YNG and CRAM 1979). Despite this, the main sources of error are the sampling technique and a large number of GC process-phenomena associated with sampling.

\section{Sample preparation}

Most of the naturally occurring reserve fats have the structure of triacylglycerols. These neutral fats are best extracted using non-polar organic solvents such as petroleum ether or chloroform (THIEle 1979). The fat is saponified and the fatty acids are converted into more volatile derivatives such as methyl esters using e.g. methanolic bortrifluoride (ACKMAN et al. 1971, Slover and LANZA 1979) or methanolic sulphuric acid (SEBEDIo and ACKMAN 1978). Transesterification, which is done in water-free conditions using sodium methoxide as catalyst, is a fast method which is widely used. A number of modifications of the method have been presented in the literature (Thies 1971, ACKMAn et al. 1977, Johansson and UpPStröm 1978, Hiltunen et al. 1979, Badings and de Jong (1983). Metcalf and WANG (1981) and BADINGS and de JoNG (1983) have, for instance, used derivatization of the free fatty acids in connection with transesterification in their work.

In the analysis of complicated mixtures of isomers produced in the hydrogenation of fatty oils, the cis and trans forms are co-eluted on a number of columns. Therefore, a preparative separation before quantification has been found necessary. In addition to gas chro- 
matographic fractionation, other possible methods include column and thin-layer chromatography and, more recently, high performance liquid chromatography (HPLC). The last-mentioned method has been used by e.g. Sebedio et al. (1982) and Svensson et al. (1982). Separation of positional and geometrical isomers of mono-unsaturated fatty acids in GC analysis is such a difficult task that it is often taken as a measure of the resolution when comparing stationary phases.

\section{Stationary phases}

The best separation is achieved in fatty-acid analysis using polar stationary phases. JAEGER et al. (1975) analysed a number of isomers using a 50-m glass capillary column containing an FFAP polyether phase, but found

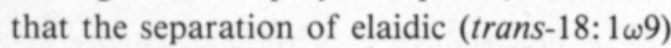

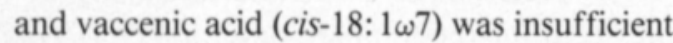
for automatic integration. According to SisFONTES et al. (1981), exact quantification of isomers is not possible in the analysis of hydrogenated oils using a Silar 10C column (50 $\mathrm{m})$. An extremely polar cyanopropyl siloxane phase (SP 2340) has been used by e.g. HECKers et al. (1977) and Slover and Lanza (1979) and Lanza and Slover (1981). The last-mentioned authors achieved good precision with very long columns $(60-100 \mathrm{~m})$ in analysing the trans fatty-acid contents of foodstuffs. Quite recently, Bоноv et al. (1984) separated the four isomers of linoleic and oleic acid using this phase on a 78-m-long capillary column. The authors noted, in addition, that the separation number $(\mathrm{TZ}=$ $0.26 / \mathrm{m}$ ) was considerably smaller than that obtained by JAEGER et al. (1975) using an FFAP column $(\mathrm{TZ}=0.93 / \mathrm{m})$. Simultaneous analysis of esterified and free fatty acids on an OV-351 silica capillary column $(15 \mathrm{~m})$ has been utilized in clinical studies carried out by PentTILÄ et al. (1984). Since unprocessed fatty oils do not in practice contain any trans fatty acids, the resolution of even short columns (Carbowax 20M, $15 \mathrm{~m}$; Silar 10C, $25 \mathrm{~m}$ ) is sufficient for screening tests where the time taken to carry out the analysis is of decisive importance (Lercker 1983, Arrendale 1983).

\section{Conventional sampling methods}

Sampling techniques have received special attention in recent years. One of the greatest drawbacks of such methods is considered to be the use of high temperatures for vaporizing the sample. The traditional split and splitless injection techniques have proved to be unreliable both as regards precision and accuracy. The main reasons for this are decomposition of the components and selective volatilization of different-sized molecules from the injector needle, which in turn results in an unequal distribution between the split and the column. The split ratio can also vary as a result of pressure effects in the injector caused by different-sized sample volumes (Sсномburg et al. 1977, Grob and Neukom 1979, Schomburg 1979, Galli and Trestianu 1981). Comparison of different injection methods in fatty-acid analysis has shown that the split ratio and sample size have a decisive effect on the quantitative results (HILTUNEN et al. 1982). In addition to these discriminating factors, adsorption of the components on the needle, septum and injector, and a reduction in resolution caused by the presence of nonvolatile contaminants, are all possible sources of error (Grob and Neukom 1979, Grob and Grob 1979).

According to Schomburg et al. (1977), achieving optimal quantitative and qualitative results presupposes:

- sufficient resolution

- high reproducibility of retention

- high precision and accuracy in quantification, i.e. there is no discrimination of the components with respect to volatilization, polarity or concentration, and

- there is minimal thermal and catalytic degradation of labile components.

In addition to the instrumental errors, factors attributable to the sample preparation such as incomplete esterification, side reac- 
tions, evaporation, adsorption or inaccuracies in the isolation process should also be taken into account (BADINGS and de JoNG 1983).

\section{Cold sampling methods}

The direct, cold on-column injection method involves transferring the sample onto the column without a vaporizing injector (SсномBurg et al. 1977, Grob and Grob 1978). The on-column technique has been found to be indisputably superior to the split and splitless methods in comparative studies and, as a result of eliminating the discrimination phenomena, it has been possible to achieve considerably better analytical precision and accuracy (Schomburg et al. 1981, Munari and Trestianu 1981). Volatilization of the sample before reaching the column can be prevented using a secondary cooling system. This ensures that the total sample is transferred onto the column (GALLI and TRESTIANU 1981).

Deterioration will occur in the separation efficiency of the column unless relatively pure samples are used in the on-column technique, i.e. no non-volatile contaminants should be introduced into the column (Groв 1978). Fast injection of large sample volumes should also be avoided in order to prevent back-flushing of excess volatilized sample from the column. Thus the temperature of the column should not be greater than the boiling point of the solvent (Groв and Neuком 1980). Despite the excellent precision and accuracy, the resolution can sometimes be considerably inferior to that obtained with split injection. The most problematic factors causing band-broadening in the on-column technique are large sample volumes and, in particular, the injection of polar solvents into non-polar columns (GROB 1981, SANDRA et al. 1983).

A programmed temperature vaporizer (PTV), in which the sample is vaporized following injection at a low temperature by raising the temperature quickly to the final level, is the latest type of injection technique. This system permits cold splitless injection, the split method with a cold or hot injector, and a special solvent elimination technique. The last-mentioned method can be used if the difference between the boiling points of the solvent and the components to be analyzed is sufficiently large. Opening and closing the split valve can be regulated automatically using a programming unit (Poy et al. 1981, Poy 1982). SchombURG et al. (1983 a) have since developed a temperature-programmed (TP) injector. CAPLAN and CRonin (1983) have presented a special version of their "solventfree» injection system, in which the solvent is removed in the tube prior to the sample being transferred into the injector, and have applied the technique in fatty-acid analysis.

\section{Precision of the analyses}

The precision of a method is usually expressed using the standard deviation (S.D.) or the relative standard deviation $\left(\mathrm{S}_{\mathrm{rel}}, \%\right)$, i.e. the coefficient of variation (C.V. \%). The precision of different injection methods is presented in Table 1. The data published by the authors are not reported here in full in all cases, and in order to obtain a uniform comparison the C.V. values for samples $\mathrm{C}$ and $\mathrm{D}$ are derived from the mean and S.D. values of the original fatty acid data.

A satisfactory precision level in the highresolution capillary technique is considered to be less than $1 \%$ (C.V.) when determined from the normalized area of the peaks (YANG et al. 1978).

\section{B. Breeding for fatty acid composition in rapeseed oil}

Evidence indicating the use of Brassica seed oil for cooking, illumination and medicinal purposes already in ancient times indicates that these plants have been among the earliest ones domesticated by man. Almost every plant part, such as the roots, stems; leaves and seeds, have been utilized and different forms of Brassica species have been developed 
Table 1. Precision of fatty-acid analyses (C.V. \%) calculated from the normalized data.

\begin{tabular}{|c|c|c|c|c|c|c|c|c|c|c|c|c|c|c|}
\hline \multirow{4}{*}{$\begin{array}{l}\text { Fatty } \\
\text { acid }\end{array}$} & \multicolumn{14}{|c|}{ Sampling technique } \\
\hline & \multicolumn{6}{|c|}{ Conventional split } & \multicolumn{6}{|c|}{ On-column } & \multirow{2}{*}{\multicolumn{2}{|c|}{$\frac{\begin{array}{c}\text { "Solvent-free } \\
\text { injection" }\end{array}}{\mathrm{F}}$}} \\
\hline & \multicolumn{2}{|c|}{ A } & \multicolumn{2}{|c|}{ B } & \multicolumn{2}{|c|}{$\mathrm{C}$} & \multicolumn{2}{|c|}{ A } & \multicolumn{2}{|c|}{ D } & \multicolumn{2}{|c|}{ E } & & \\
\hline & Mean & C.V. & Mean & C.V. & Mean & C.V.* & Mean & C.V. & Mean & C.V.* & Mean & C.V. & Mean & C.V. \\
\hline 16:0 & 3.0 & 2.1 & 15.2 & 1.7 & 26.5 & 3.9 & 3.0 & 2.7 & 23.4 & 0.9 & 24.7 & 0.2 & 6.3 & 1.6 \\
\hline $18: 0$ & 1.6 & 2.4 & 11.8 & 1.1 & 9.3 & 2.7 & 1.4 & 0.5 & 11.6 & 0.5 & 33.5 & 0.2 & 4.8 & 0.6 \\
\hline $18: 1 \omega 9$ & 58.6 & 0.3 & 22.9 & 1.3 & 30.1 & 1.0 & 57.6 & 0.1 & 27.9 & 0.7 & 32.9 & 0.2 & 19.0 & 0.3 \\
\hline $18: 1 \omega 7$ & & & 1.9 & 1.2 & & & & & & & & & & \\
\hline $18: 2 \omega 6$ & 20.2 & 0.5 & 17.8 & 1.3 & 6.8 & 4.3 & 20.7 & 0.5 & 1.5 & 1.5 & 3.2 & 0.3 & 14.4 & 0.4 \\
\hline $18: 3 \omega 3$ & 12.7 & 0.5 & 1.1 & 2.3 & 1.1 & 6.5 & 13.0 & 0.3 & 2.5 & 2.3 & 1.1 & 0.7 & 55.4 & 0.1 \\
\hline $20: 0$ & 0.5 & 8.1 & 0.4 & 4.8 & & & 0.4 & 1.8 & 0.6 & 4.4 & 1.1 & 0.9 & & \\
\hline 20: $1 \omega 9$ & 1.7 & 6.7 & & & & & 1.8 & 2.2 & & & & & & \\
\hline $20: 2 \omega 6$ & 0.2 & 21.6 & & & & & 0.2 & 5.2 & & & & & & \\
\hline $22: 0$ & 0.3 & 14.1 & & & & & 0.2 & 4.7 & & & 0.5 & 3.7 & & \\
\hline $22: 1 \omega 9$ & 1.3 & 7.8 & & & & & 1.7 & 3.5 & & & & & & \\
\hline
\end{tabular}

Samples:

A Rapeseed oil (Hiltunen et al. 1982) (I) D Milk fat (BADINGS and de Jong 1983)

B Shortening (Slover and Lanza 1979) E Cocoa butter (Geeraert et al. 1983)

C Human milk lipids (Haug et al. 1983) F Linseed oil (CAPLAN and CRonin 1983)

* includes extraction, methylation and GLC

through natural selection and breeding (DowNEY 1983).

Turnip rape (B. campestris L. ssp. oleife$\mathrm{ra}$ ) is one of the basic oilseed species in the Cruciferae family, which by an interspecific cross with cabbage (B. oleracea L.) produces an amphidiploid rape (B. napus L. ssp. oleifera). Turnip rape is also a parental species for Indian mustard (B. juncea (L.) Czern.) (Bengtsson et al. 1972, Downey 1983). In the recent literature new systematic names for the family (Brassicaceae), turnip rape (B. rapa ssp. oleifera or B. rapa var. silvestris) and rape (B. napus ssp. napus or B. napus L. var. napus) have been given (EHRENDORFER 1983, FroHNE and JENSEN 1985).

The development of new rapeseed varieties during the last twenty years has provided the foodstuff, animal-feed and chemical industries with an ever more versatile source of rawmaterials. This success is primarily due to the changes brought about in the fatty acid composition, which is considered to be one of the greatest efforts made in the area of plant breeding.

\section{Biogenetic dependances}

The formation of oleic acid plays a key role in the biosynthesis of fatty acids in plants. The chloroplasts of the leaf tissue and the proplastids of the embryo are most probably the only site of de novo synthesis involving the formation of palmitoyl-, stearoyl- and oleylACP (acyl carrier protein) complexes. OleylACP (18:1 ACP, Scheme 1) is hydrolyzed rapidly by an enzyme and the product, oleic acid, is transported from the organelles to the cytoplasm where it is subsequently modified in a number of reactions (Scheme 1) (STUMPF and Pollard 1983).

It has been proposed that the fatty acids in rapeseed are formed via the following biogenetic pathways (Scheme 2). The scheme is based on literature presented by DOWNEY and Craig (1964), Appelqvist (1968), Thies (1968), Brar and ThIEs (1978) and Downey (1983).

Direct biosynthetic studies carried out with ${ }^{14} \mathrm{C}$-labeled precursors have shown that eicosenoic (20:1 $1 \omega 9)$ and erucic acids $(22: 1 \omega 9)$ are 


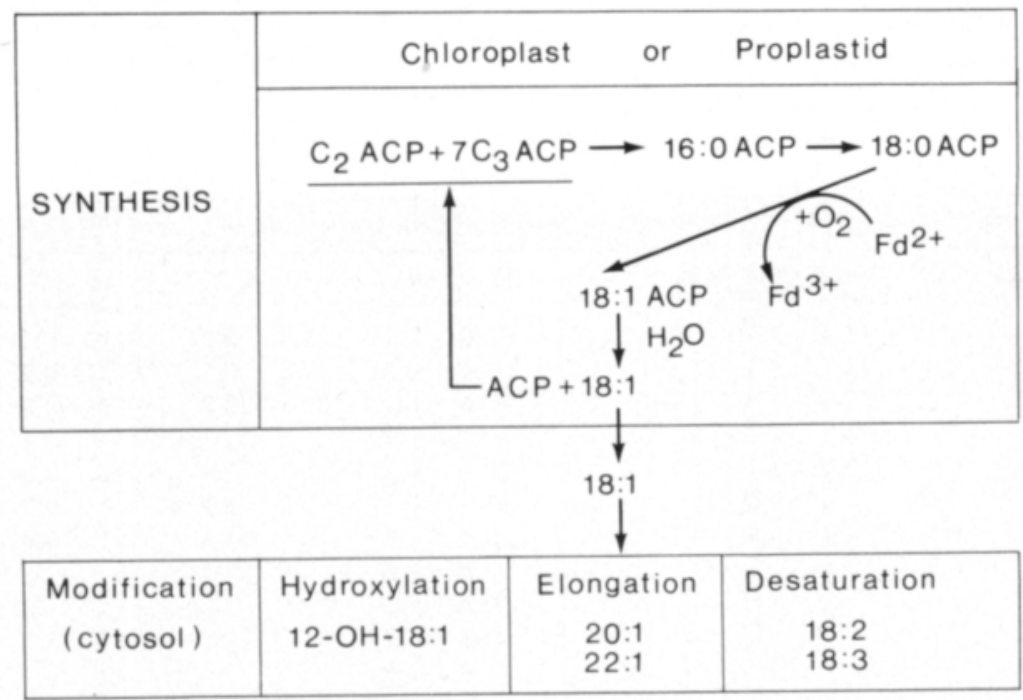

Scheme 1. The role of oleic acid in the synthesis of fatty acids in different plant tissues.

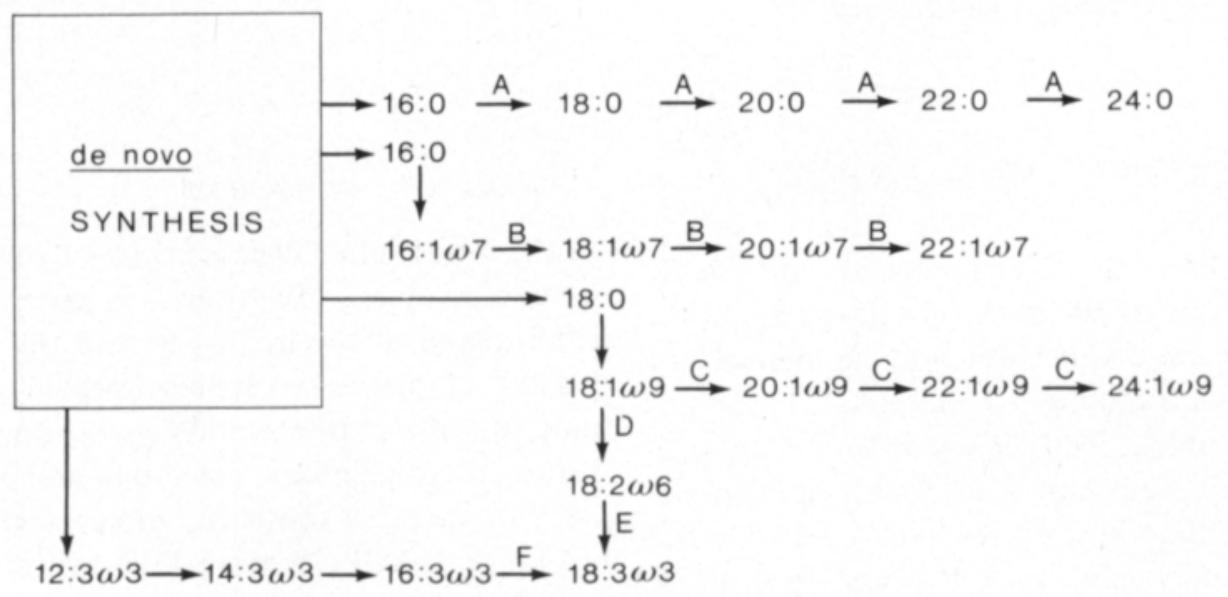

Scheme 2. Biogenesis of rapeseed fatty acids.

formed from oleic acid $(18: 1 \omega 9)$ as a result of chain elongation (pathway C, Scheme 2) (Downey and Craig 1964). Multiple alleles located at a single locus in diploid turnip rape control the synthesis of these $\mathrm{C}_{20}-\mathrm{C}_{22}$ components (JÖNSSON 1977 a). DOWNEY and Craig (1964) found, furthermore, that the formation of saturated fatty acids (pathway A) is relatively independent of changes in monoenoic components (pathway C). Since genetical blocking of the formation of eico- senoic and erucic acids also results in the inhibition of the formation of the corresponding $1 \omega 7$ isomers (pathway B), parallel elongation of $1 \omega 9$ and $1 \omega 7$ components is assumed to be under the control of a single genetic system (APPElqvist 1968). The main pathway of polyunsaturated fatty acids starts with the desaturation of oleic acid into linoleic acid $(18: 2 \omega 6)$ and subsequently $\alpha$-linolenic acid $(18: 3 \omega 3)$ (pathway D). Biosynthetic studies carried out on rape embryos have shown that 
hexadecatrienoic acid $(16: 3 \omega 3)$ is also a possible precursor of $\alpha$-linolenic acid (pathway F) Brar and Thies 1978). RaKow (1973) has earlier suggested that two independent enzyme systems are involved in the production of $\alpha$ linolenic acid.

A number of genes have been found to control the linoleic and $\alpha$-linolenic acid levels in rape (KondRA and Thomas 1975). If $\alpha$ linolenic acid is formed through two pathways (D and F, Scheme 2), then they are controlled at two locii in turnip rape and at four locii in amphidiploid rape. Thus one allele would determine only $1 / 8$ of the total $\alpha$-linolenic acid content in rape (Stefansson 1983). The $\alpha$ linolenic and oleic acid contents are determined genetically by the genotype of the mother plant alone, and not that of the embryo. The linoleic acid level is mainly regulated by the mother plant, the effect of the genotype of the embryo being four times smaller. In addition, environmental conditions have also been found to modify considerably the contents of these $C_{18}$ fatty acids (BARTKOWIAK-BRODA 1983).

As far as breeding work is concerned, the frequently rather high correlations which exist between the fatty acids in rapeseed oil have provided useful, although indirect, evidence for the biogenetic interrelationships between these components. The unusually high negative correlation $(r=-0.975)$ found in biological material between oleic and erucic acids by Craig (1961), has since been shown to be a biosynthetic relationship (DOWNEY, and CralG 1964). The situation between eicosenoic and erucic acid is, however, more complicated since the correlation is positive up to an erucic acid content of $25 \%$, and becomes negative at higher levels (JönSSON 1977 a). Oleic acid is, furthermore, a precursor of linoleic acid (STEARns 1970). According to KONDRA and ThOMAs (1975), the similar behaviour of these fatty acids in crossings, as well the very high negative correlation, indicates that the formation of linoleic acid is controlled by a single gene system. On the other hand, the correlation between linoleic and $\alpha$-linolenic acids is considerably smaller than the above and, in addition to ordinary positive correlation, negative correlations have also been occasionally found (KONDRA and WILSON 1976, JöNSSON 1975 a).

\section{Erucic acid-free rapeseed oil}

The variation in the erucic acid content was found, already many years ago, to be important when comparing different varieties of rape in breeding programmes (CRAIG and WeTtER, 1959). The half-seed technique proved to be a valuable tool in breeding work, especially after the erucic acid content was found to be determined on the basis of the genotype of the embryo (HARVEY and DowNEY 1964). In this method, one of the cotyledons of the embryo is analysed and the other one allowed to develop into a normal plant (Downey and Harvey 1963, Thies 1971).

Erucic acid-free seed material was found in rape varieties (Stefansson et al. 1961, SteFANSSON and Hougen 1964) and turnip rape varieties (DOWNEY 1964) already at the beginning of the 1960's. However, these varieties did not fully meet the requirements when grown under European conditions, and hence they had to be crossed with European varieties (RöbBELEN 1976). Varieties which have already become adapted have been used by, e.g. JöNSSON (1973), in breeding erucic acid-free turnip rape.

The typical composition of high and low erucic-acid rapeseed oil is presented in Table 2.

In addition to oleic acid, the most marked change has taken place in the amounts of the polyunsaturated acids, linoleic and $\alpha$ linolenic, which have approximately doubled in comparison to the levels in traditional rapeseed oil (Table 2). Analytical studies on the isomers have, furthermore, shown that the vaccenic acid content $(18: 1 \omega 7)$ rises to rather high levels, even to over $3 \%$, in low erucicacid material (Hougen and WAsowicz 1978). 
Table 2. Fatty acid composition of a traditional and a new rapeseed variety.

\begin{tabular}{lcc}
\hline Compound & $\begin{array}{c}\text { Traditional } \\
\text { rapeseed oil } \\
\text { Mean }(\%)\end{array}$ & $\begin{array}{c}\text { New } \\
\text { rapeseed oil }{ }^{2} \\
\text { Mean }(\%)\end{array}$ \\
\hline $16: 0$ & 4.0 & 3.8 \\
$18: 0$ & 1.3 & 1.2 \\
$18: 1 \omega 9$ & 16.4 & 53.5 \\
$18: 1 \omega 7$ & 1.0 & \\
$18: 2 \omega 6$ & 12.7 & 23.5 \\
$18: 3 \omega 3$ & 5.3 & 14.0 \\
$20: 0$ & 0.9 & 0.3 \\
$20: 1 \omega 9$ & 9.0 & 1.4 \\
$20: 1 \omega 7$ & 1.4 & 0.1 \\
$20: 2 \omega 6$ & 0.3 & 0.2 \\
$22: 0$ & 0.6 & 1.0 \\
$22: 1 \omega 9$ & 44.4 & \\
$22: 1 \omega 7$ & 1.2 & \\
\hline
\end{tabular}

1 Ackman 1966, 2 Ackman \& Sebedio 1978

Only very small amounts $(\sim 0.01 \%)$ of trans isomers, which are usually $\mathrm{C}_{15}$ fatty acids, have been found in unprocessed rapeseed oil (Sebedio and Ackman 1979).

The oil content of rapeseed is usually about $40-50 \%$, most of it (c. $95 \%)$ in the form of triacylglycerols (APPELQvisT 1972). Replacement of erucic acid by a fatty acid with a smaller molecule (i.e. oleic acid) has thus, to some extent, resulted in a reduction in the total amount of oil. Despite the low variation, it has been possible to increase the oil content by applying continuous selection (KRZYMAŃsKI 1984), and by favouring yellow-seeded material, which also has a lower fibre content, over the brown-seeded form (JöNSSON $1975 \mathrm{~b})$. The above-mentioned changes in the composition have naturally increased the commercial possibilities of utilizing erucic acidfree rapeseed oil in the foodstuff industry. A new term ("Canola") has been adopted in e.g. Canada, to differentiate new rapeseed production from that of traditional rapeseed varieties (PAszKowski 1983).

\section{Breeding for polyunsaturated fatty acids}

After the erucic acid problem had been solved, the primary task in the breeding of new varieties has been to bring about a con- siderable increase in the amount of essential linoleic acid as opposed to the normal $(20-22 \%)$ level. Furthermore, the $\alpha$-linolenic acid content should be decreased from the present level of $10-12 \%$, down to as low a level as possible (c. 3-4 \%). Being an easily oxidized component, $\alpha$-linolenic acid is particularly problematic for the margarine industry. Other aims of breeding are considered to be a relatively high content of $(\sim 10 \%)$ palmitic acid (16:0) in order to improve the physical properties of the fat (THIES 1968, DOWNEY and McGregor 1975, Röbbelen 1983, JönsSON and PERSSON 1983).

Since the variation in the amounts of polyunsaturated fatty acids is relatively small, it has been suggested that the genetic variability could be increased by treating the seed material with mutagens (THIES 1968). RAKOw (1973) has observed considerable differences, independent of the linoleic acid content, in the $\alpha$-linolenic acid level (4-20\%) in material induced in this way. According to RöBBELEN and NiTSCH (1975), it is not promising to select for linoleic and $\alpha$-linolenic acid contents simultaneously in order to obtain the desired combination of these polyenoic fatty acids.

Relatively high heritability values $\left(\mathrm{h}^{2}\right)$ of 0.56 (BARTKOWIAK-BRODA 1978), 0.26-0.59 (Kondra and Thomas 1975) for rape and $0.44-0.76$ for turnip rape (JönSSON 1975 a) have been obtained for linoleic acid in controlled crossings. JönssON (1975 a) has noted that the effect of the environment is considerably lower than would be expected and that increasing the linoleic acid level of summer turnip rape up to $40 \%$ is a realistic target. Such results could be obtained by using the half-seed technique and carrying out the breeding experiments in the greenhouse where constant conditions can be maintained, e.g. with respect to day length and temperature.

The first marked changes with respect to polyunsaturated fatty acids were found in rape material treated with a mutagen. The low $\alpha$ linolenic acid content (4\%) was combined with a high linoleic acid level (40\%) (RöвBELEN and NitsCh 1975). JönsSON and Pers- 
SON (1983) have since used this material in their breeding experiments and achieved even higher linoleic acid contents. Since, in addition, the amount of palmitic acid increased at the same time up to $10 \%$, the fatty acid profile was rather close to the composition of soybean oil. Achieving such a composition for summer turnip rape too, supports the $50 \%$ linoleic acid content found in its seed.

Cross pollination restricts the breeding of turnip rape, and selfpollination cannot be utilized in the same way as with rape. The combination and retention of improvements in the quality of cultivable material, however, form the most problematic stage since a number of factors have to be taken into account. The material should primarily be resistant to the weather, insect pests and plant pathogens, and to fulfill the quantity and quality criteria set on the yield before it can be considered as a variety suitable for commercial use (LööF and APPElQvist 1972).

\section{The role of polyunsaturated fatty acids in the diet}

Linoleic $(18: 2 \omega 6)$ and $\alpha$-linolenic acid $(18: 3 \omega 3)$ are both essential constituents for human physiology because the body is not capable of synthesising them or interconverting these two fatty acid series ( $\omega 6$ and $\omega 3$ ) (HoLMAN 1970). These fatty acids have, as is usually the case with naturally occurring unsaturated fatty acids, a cis configuration (Thiele 1979). Retention of this configuration in the structure of linoleic and $\alpha$-linolenic acids is further a basic prerequisite for the formation of the prostaglandin precursors such as homogammalinolenic $(20: 3 \omega 6)$, arachidonic $(20: 4 \omega 6)$ and eicosapentaenoic acids

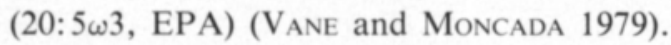
The enzyme, $\Delta^{6}$ desaturase, which can be inhibited by a number of factors such as saturated and trans fatty acids, plays a central role in the formation of these precursors (HoRroBIN 1982). $\alpha$-Linolenic acid also has an inhibitory effect when linoleic acid is being meta- bolized into arachidonic acid (HoLman 1970, SEHER et al. 1983). When the desaturation stage of linoleic acid is passed, its following

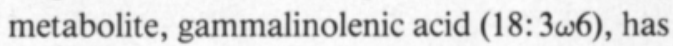
a clearly more pronounced effect than its precursor (HoRRoBIN 1982). The $\omega 3$ fatty acids have been looked at in a new light during the last few years following the finding that a fish diet, and especially the EPA to be found in fish, have a beneficial effect on the functioning of the heart and circulatory system (Dyerberg et al. 1978, Hamilton et al. 1980, HAY et al. 1982).

The large amount of fat and high proportion of saturated fatty acids in the diet of western peoples is considered to be a significant factor contributing towards the high incidence of cardiac and circulatory diseases (GANDER 1984, Oster and Schlierf 1982). However, this is not necessarily a result of the increase in the consumption of fats proper (butter, margarine, vegetable oils), but rather the considerable rise in the proportion of so-called hidden fats in the diet (Fondu 1981, Masson 1981). In the Finnish diet, these hidden fats can constitute as much as over $50 \%$ of the total intake of fat (ANON 1981).

Monitoring studies carried out on sections of the Finnish population have shown that there is a connection between a high level of saturated and low level of polyunsaturated fatty acids in the serum phospholipids and the incidence of ischaemic heart disease (MIETTINEN et al. 1982). In addition, the serum selenium level has been found to be lower in highrisk groups (MietTINEN et al. 1983). A high cholesterol level is also considered to be a result of too high a fat consumption and an imbalance between the intake of saturated and polyunsaturated fatty acids (VARTIAINEN et al. 1984).

Fish offers excellent possibilities for achieving a balanced intake of fats since the proportion of polyunsaturated fatty acids in the lipids of the flesh and roe of the fish commonly eaten can be as high as $50 \%$ even (KAITARANTA 1981). The $\omega 6 / \omega 3$ fatty acid ratio in fish oil is extremely low $(0.1-0.3)$. In contrast, the 
most balanced ratio in vegetable oils along with increasing $\alpha$-linolenic acid content is in soybean (7.0), rapeseed (1.9) and linseed oils (0.3) (LAAKSo et al. 1984). Some vegetable oils, such as sunflower and safflower oils, have a ratio of as high as $150-220 / 1$ even. In England, the preference for vegetable oils of this type is considered to have had a detrimental effect, along with the decrease in the consumption of fish, on the intake of $\omega 3$ fatty acids. One proposed solution to this problem is the addition of $\alpha$-linolenic acid to edible oils such as olive or soybean oils (HAMILTON et al. 1980). We have long been uncertain about the effects of $\alpha$-linolenic acid, and it has only recently been shown to act as a precursor of EPA in humans (SANDERS and Younger 1981, BudowsKi et al. 1984). A more balanced ratio of linoleic and $\alpha$-linolenic acids in the diet is being emphasized more and more, and it has even been suggested that linoleic acid has been favoured too much in the west at the expense of $\alpha$-linolenic acid (BUDOwSKI et al.
1984).

As far as rapeseed oil is concerned, early studies with laboratory animals and especially with the rat indicated that that the myocardial lesions which developed were due to the high erucic acid concentration. However, those results cannot be applied in humans as such. It is now apparent that low erucic-acid rapeseed oil is like other vegetable oils, a safe substance for human consumption (GRICE and Heggtveit 1983).

A considerable decrease in the serum cholesterol level has been described after a fat diet containing rapeseed oil in a number of studies as reviewed by McDonAld (1983). Rapeseed oil has been found to be effective in decreasing the total cholesterol and increasing the HDL cholesterol levels also in the treatment of familial hypercholesterolemia (SAvore et al. 1983). One of the most important findings is that rapeseed oil is capable of increasing the eicosapentaenoic acid (EPA) content in the serum (LASSERE and JACOTOT 1983). 


\section{Experimental}

\section{A. Materials}

The practical breeding work and yield trials included in the present study have been done at Hankkija Plant Breeding Institute at $\mathrm{Hy}$ rylä in 1978-85. The starting material was two summer turnip rape populations of $\mathrm{Ca}$ nadian origin which were erucic acid-free, had a low glucosinolate content and about $70 \%$ yellow seed. The two populations are referred to in the text as numbers 7622 and 7629 . In addition to the breeding tests, these populations were also used as the control material. Material grown in the greenhouse or in the field are marked with the symbols G (greenhouse) and F (field). The breeding programme, which is described in detail in papers II, IV and V, is summarized in Scheme 3.

The individuals with the best agronomic properties were always taken for further breeding via phenotypic selection, and the final selection of the linoleic acid lines was done on the basis of the yields. The yield trials have been carried out parallely on summer turnip rape varieties (e.g. Emma, Ante and Span) commonly cultivated in Finland (VII).

\section{B. Methods}

\section{Analytical methods}

Usually c. $10-15$ seeds $(30-50 \mathrm{mg})$ were taken the from the yield of each individual and the fatty acids derivatized using the transesterification method described by HILTUNEN et al. (1979). The gās chromatographic analyses were done using glass capillary columns on a number of different instruments. The rou- tine analyses were carried out on a Carlo Erba Fractovap 2300 and a Dani 3200 GC fitted with a split-splitless injector system. FFAP (free fatty acid phase) was used as the phase on the columns of different length, and the runs were usually carried out at $200^{\circ} \mathrm{C}$ using hydrogen $\left(\mathrm{H}_{2}\right)$ as the carrier gas. All the instruments were fitted with a flame ionization detector (FID). The split ratio was set at 15:1, and the amount of sample injected was $1 \mu \mathrm{l}$ (I, III).

A 55-m-long FFAP column, pretreated with an aqueous solution of $\mathrm{Ba}(\mathrm{OH})_{2}$ and carbon dioxide in order to form a layer of barium carbonate, was prepared for the isomer studies (III) (Grob and Grob 1976). The phase dissolved in dichlormethane was run through the column using the dynamic, so-called mercury drop method according to ScHOMBURG and Husman (1975).

A Dani 3200 gas chromatograph fitted with an on-column injector and a secondary cooling system was used in comparing different injection techniques. The injection temperature in the on-column analysis was $35^{\circ} \mathrm{C}$, and the oven programmed to $210^{\circ} \mathrm{C}$ at a rate of $10^{\circ} \mathrm{C} / \mathrm{min}(\mathrm{I})$.

The fatty acid analyses were further run on a Dani HR 3800 PTV instrument fitted with a PTV (programmed temperature vaporizer) injector and control unit (PTV 382). The column was a FFAP $(15 \mathrm{~m}$, i.d. $0.33 \mathrm{~mm})$ and the carrier gas hydrogen $\left(\mathrm{H}_{2}\right.$, flow rate 2.5 $\mathrm{ml} / \mathrm{min})$. In the solvent split method an initial injector temperature of $70^{\circ} \mathrm{C}$ was used. 
Scheme 3.

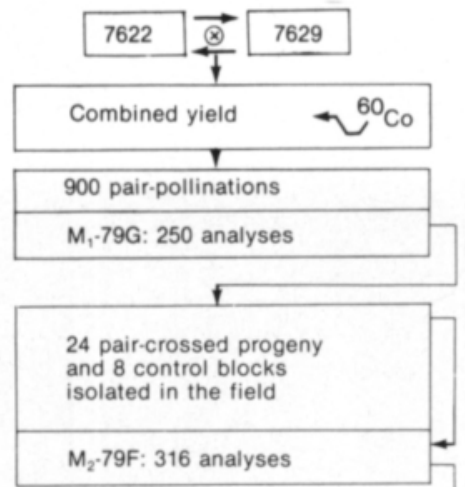

\begin{tabular}{|l|}
\hline $\begin{array}{l}4 \text { pair-crossings between } \\
\text { pairs, also between } \\
\text { controls }\end{array}$ \\
\hline $\mathrm{M}_{3}-80 \mathrm{G}: 172$ analyses \\
\hline $\begin{array}{l}63 \text { pair-crossing progeny } \\
\text { and } 7 \text { control blocks isolated } \\
\text { in the field }\end{array}$ \\
\hline 83 block yield analyses \\
\hline
\end{tabular}

\begin{tabular}{|l|}
\hline $\mathrm{M}_{4}-80 \mathrm{~F}: 128$ analyses \\
$\begin{array}{l}16 \text { progeny and control } \\
\text { blocks isolated in the } \\
\text { field }\end{array}$ \\
\hline $\mathrm{M}_{5}-81 \mathrm{~F}: 261$ analyses \\
\hline
\end{tabular}

\begin{tabular}{l}
15 progeny and control \\
blocks isolated in the \\
field \\
\hline $\mathrm{M}_{6}-82 \mathrm{~F}: 512$ analyses \\
\hline
\end{tabular}

\begin{tabular}{l}
24 progeny and control \\
blocks isolated in the \\
field \\
\hline$M_{r}-83 \mathrm{~F}: 478$ analyses \\
\hline $\begin{array}{l}10 \text { progeny and control } \\
\text { blocks isolated in the } \\
\text { field }\end{array}$ \\
\hline$M_{8}-84 \mathrm{~F}: 185$ analyses \\
\hline
\end{tabular}

30 individuals pollinated with mixed pollen from another population

Irradiation (40 krad)

Yields combined by pairs

Linoleic-acid selection, 24 of the best progenies taken as breeding material

Phenotypic selection, 10 open-pollinated individuals from each progeny and control

(II)

Linoleic-acid selection, 2 of the best individuals to be grown in the greenhouse from each progeny and control

Linoleic-acid selection, 21 of the best progenies for continuation

Phenotypic selection, 5 open-pollinated individuals from each progeny

Linoleic-acid selection, 32 of the best individuals for continuation, 16 pairs formed, yields of the pairs combined

\section{Phenotypic selection}

Linoleic-acid selection, 48 of the best individuals for continuation, 15 lines formed, the yield of $3-4$ individuals for each

\section{Phenotypic selection}

(IV) Linoleic-acid selection, 77 of the best individuals for continuation, 24 lines formed

Phenotypic selection

Linoleic-acid selection, 35 of the best individuals for continuation, 10 lines formed

\section{Phenotypic selection}

(V) 
After introducing the sample, the split was kept open for $8 \mathrm{~s}$. The split was then closed, the injector temperature increased to $250^{\circ} \mathrm{C}$, and the split then opened again after $70 \mathrm{~s}$. The oven was programmed from $70^{\circ} \mathrm{C}$ to $205^{\circ} \mathrm{C}$ at a rate of $10^{\circ} \mathrm{C} / \mathrm{min}(\mathrm{VI})$.

The area of the peaks was determined on Infotronics CSR-208, Hewlett-Packard 3390A or Shimadzu C-R1B integrators, and normalized to $100 \%$ before carrying out statistical analysis (I, III, IV).

The components were identified by comparing them with the retention times (III) for pure compounds of the fatty acid methyl esters (Applied Science Labs.; Nu Chek Prep. Inc.), and mass spectrometrically using a HewlettPackard 5890 GC fitted with an HP 5970 mass selective detector (VI). The precision and accuracy of the analytical conditions were optimized on the basis of the results obtained with the on-column method and a mixture of pure compounds (I).
The raw fat content of the breeding material was determined using the NIR (near infrared reflectance) technique (VII).

\section{Statistical analysis}

The Student's t-test was used in comparing the mean values. The equality of variances was studied using the F test, and when necessary a modification of the t-test was applied according to equations by SNEDECOR and $\mathrm{COCH}$ RAN (1973) (I, II, IV-VI). The heritability of linoleic acid was determined in two separate generations using the offspring-midparent equation $\left(h^{2}=b_{O P}\right)$, and with the realized heritability $\left(\mathrm{h}^{2}=\mathrm{R} / \mathrm{S}\right)$ for the whole material throughout the course of the breeding period (SimmondS 1979, Falconer 1981) (IV, V). Analyses of correlation and variance, as well as comparison between two correlation coefficients, were carried out using the equations presented in the literature (SNEDECOR and Cochran 1973) (II, III, V). 


\section{Results}

\section{A. Gas chromatography}

The variation in the fatty acid isomers in the heterogeneous seed material was studied using an FFAP column (55 mm) especially prepared for this purpose. A gas chromatogram of the fatty acids in traditional rapeseed oil is presented in Fig. 1 (III).

A total of 13 different components were identified. $1 \omega 7$ isomers were represented by vaccenic, 13-eicosenoic and 15-docosenoic acids (peaks 4, 9 and 13 in Fig. 1). The re- sults obtained following the esterification of triolein, which is a compound where the acyl groups are formed only from oleic acid (18: $1 \omega 9)$, showed that neither the esterification method nor gas chromatography resulted in the conversion of oleic acid to vaccenic acid (III).

\section{Conventional vs. on-column technique}

The significance of sample injection in the fatty acid analysis of rapeseed oil was studied

Fig. 1. The fatty acid composition of a high erucic acid rapeseed variety.

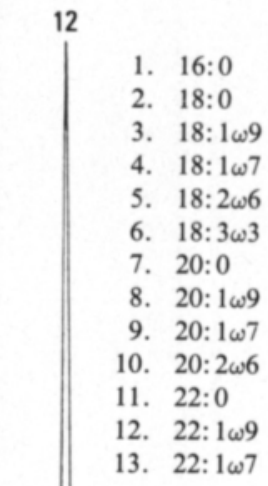


in detail using a number of different instruments (I, III, VI). The conventional split technique was compared with the on-column method, and the variation and differences between the means were tested statistically (I). The mean precision of the two methods for 13 fatty acid compounds is presented in Table 3 .

Table 3. Estimates of the precision of the conventional split and on-column techniques.

\begin{tabular}{lccc}
\hline Method & $\begin{array}{c}\text { Split } \\
\text { (I) }\end{array}$ & $\begin{array}{c}\text { Split } \\
\text { (III) }\end{array}$ & $\begin{array}{c}\text { On-column } \\
\text { (I) }\end{array}$ \\
\hline $\begin{array}{l}\text { Mean precision } \\
\text { (C.V. \%) }\end{array}$ & 6.4 & 5.7 & 2.3 \\
\hline
\end{tabular}

The results show that the precision of the on-column method is clearly superior to that of the split technique. Compared to the oncolumn analyses, the variation in the $\mathrm{C}_{20}-$ $\mathrm{C}_{22}$ fatty acids with the split method was greater $(\mathrm{P}<0.01)$, and also a large number of highly significant differences were obtained between the mean values (I).

The effect of the sample size and the split ratio on the quantitative results of the split technique was studied using low erucic acid samples, and the results then compared to those obtained with the splitless and oncolumn methods (I) (Table 4).

The use of a large sample size $(2.4 \mu \mathrm{l}$, Table 4 ) or small split ratio (3:1) resulted in a considerable analytical error when determining low erucic acid levels, the amount being in some cases less than half $(0.7 \%)$ the value obtained with the on-column method $(1.7 \%)$. With the split method the same quantitative level was obtained with a very small sample size $(0.1 \mu \mathrm{l})$ as with the splitless technique (I).

\section{Programmed temperature vaporization (PTV) techniques}

Preliminary tests with PTV showed that the splitless method has a similar precision to that of the on-column technique. The variation error in the split and solvent split runs (injections at $45^{\circ} \mathrm{C}$ and $70^{\circ} \mathrm{C}$ respectively) was found to account for about 10 and $40 \%$ respectively of the variation associated with conventional hot injection $\left(250^{\circ} \mathrm{C}\right)$. PTV split injection also gave the most accurate result compared to the on-column method (LAAKSo et al. 1983).

The precision of the PTV solvent split technique was determined using samples with different erucic acid contents. The derivatization method and the GC process were repeated by carrying out the runs on six samples taken from the same extractant (VI). The estimates of the mean precision (C.V. \%) in PTV analysis are presented in Table 5.

Table 5. Estimates of the mean precision of the instrument and the whole process in PTV analysis.

\begin{tabular}{cccc}
\hline & \multicolumn{2}{c}{ Intra-assay } & Inter-assay \\
\hline Sample & $\begin{array}{c}\text { Zero } \\
\text { erucic }\end{array}$ & $\begin{array}{c}\text { High } \\
\text { erucic }\end{array}$ & $\begin{array}{c}\text { Zero } \\
\text { erucic }\end{array}$ \\
\hline
\end{tabular}

Mean

precision

\begin{tabular}{llll} 
(C.V. \%) & 2.0 & 1.9 & 2.2 \\
\hline
\end{tabular}

Table 4. Effect of sample size and split ratio in fatty acid analysis.

\begin{tabular}{|c|c|c|c|c|c|}
\hline \multirow[t]{2}{*}{ Method } & \multirow{2}{*}{$\begin{array}{l}\text { Sample } \\
\text { size }(\mu \mathrm{l})\end{array}$} & \multirow{2}{*}{$\begin{array}{l}\text { Split } \\
\text { ratio }\end{array}$} & \multicolumn{2}{|c|}{ Peak area $(\%)$} & \multirow{2}{*}{$\begin{array}{c}\text { Peak area ratio } \\
(16: 0 / 22: 1)\end{array}$} \\
\hline & & & $16: 0$ & $22: 1$ & \\
\hline \multirow[t]{3}{*}{ Split } & 0.1 & $15: 1$ & 2.9 & 1.4 & 2.1 \\
\hline & 2.4 & $15: 1$ & 4.3 & 0.7 & 6.1 \\
\hline & 1.0 & $3: 1$ & 4.2 & 0.7 & 6.0 \\
\hline Splitless & 0.3 & - & 2.9 & 1.4 & 2.1 \\
\hline On-column & 1.0 & - & 3.0 & 1.7 & 1.8 \\
\hline
\end{tabular}


It can be concluded from Table 5 that at least the same degree of precision can be obtained using the PTV solvent split technique as with the on-column method (Table 3). The combined mean variation (mean C.V. = $2.2 \%$ ) of the esterification procedure and the GC analysis indicate that the proportion of the variation attributable to derivatization is in practice negligible (VI).

The PTV solvent split analyses were carried out on a 15-m-long FFAP column, which separated vaccenic acid (18:1 $1 \omega 7)$ from oleic acid with a precision of $4 \%$ even (VI).

The fatty acid variation in the high erucicacid (c. $7 \%$ ) seed material was determined using the conventional method (III) and the PTV technique (VI). The proportion of the analytical error (variance) was then subtracted from the total variation $(\mathrm{N}=30)$. The most marked differences between the methods are presented in Table 6.

Table 6. Proportion of biological variation as determined by two different injection techniques.

\begin{tabular}{lcccc}
\hline \multicolumn{2}{c}{ Sampling method } & & \multicolumn{2}{c}{$\begin{array}{c}\text { Variation of biological } \\
\text { origin }(\%)\end{array}$} \\
\cline { 5 - 5 } Compound & Mean (\%) & & $\begin{array}{c}\text { Conven- } \\
\text { tional } \\
\text { split }\end{array}$ & $\begin{array}{c}\text { PTV } \\
\text { solvent } \\
\end{array}$ \\
& & & (III) & split \\
& & & 78.3 & 99.4 \\
\hline $16: 0$ & 3.6 & & 66.7 & 92.6 \\
$20: 0$ & 0.4 & & 83.6 & 93.7 \\
$20: 2 \omega 6$ & 0.5 & & 68.4 & 99.3 \\
$22: 0$ & 0.2 & & &
\end{tabular}

The proportion of the analytical error caused by the conventional split method out of the total variation is approximately one quarter in the case of palmitic (16:0), arachidic $(20: 0)$, eicosadienoic $(20: 2 \omega 6)$ and behenic (22:0) acids (Table 6), while for the three main components it is below $3 \%$ (III).

With the PTV method, on the other hand, the proportion of biological variation was found to be over $90 \%$ for all the fatty acids, and in most cases the analytical error remained below $1 \%$ of the total variation (VI).

\section{B. Breeding experiments}

\section{Variation in fatty acids}

When the mode of inheritance of the fatty acids was being studied, the frequency distributions of palmitic, stearic, oleic, linoleic, $\alpha$ linolenic, arachidic and behenic acids were found to be continuous and to conform to some extent to the normal distribution. The distribution of eicosadienoic acid, on the other hand, was skewed strongly to the right and levels many times greater than the normal one $(0.1-0.2 \%)$ were found in both the bred material and in the controls. Similarly, increased concentrations of eicosenoic acid were found occasionally (II).

The effect of environmental factors on the fatty acid composition was studied by growing the control material in four different blocks in the field. The results of replicate block trials showed that the replicates did not differ significantly from each other as regards selection for linoleic acid (II).

However, the variation in the linoleic acid content of this material was approximately double when grown in the greenhouse (IV, V). Single seed analyses done on these individuals showed that there were rather large differences between different pods in the variance $\left(\mathrm{s}^{2}\right)$ of both linoleic $(0.5-7.7)$ and $\alpha$-linolenic acids (0.6-4.3) (VI).

The variance of the main components oleic, linoleic and $\alpha$-linolenic acids - in the control material never exceeded, to a significant degree, the corresponding values for the bred material, and the relative standard deviation in both materials was almost without exception below $10 \%$ (C.V.). The range for linoleic acid in different generations was about $10 \%$-units, the lowest individual content being $18.1 \%\left(\mathrm{M}_{4}\right)$ and the highest $34.1 \%$ $\left(\mathrm{M}_{8}\right)$ (II, V).

\section{The long-term effects of selection}

The linoleic acid content of every one of the generations grown in the field was significantly greater $(\mathrm{P}<0.001)$ than that of the controls, 
and the oleic acid content correspondingly lower. No statistically significant differences were found, on the other hand, in the greenhouse $\left(\mathrm{M}_{3}-80 \mathrm{G}\right)$. The smallest increase in the amount of linoleic acid achieved under field conditions was $1.7 \%$-units $\left(\mathrm{M}_{2}, \mathrm{M}_{5}\right)$, and the largest $3.8 \%$-units $\left(\mathrm{M}_{8}\right)$. The amount of eicosadienoic acid, which belongs to the same series of $\omega 6$ fatty acids, was at least significantly higher $(\mathrm{P}<0.05)$ than that in the controls (II, IV, V).

The heritability $\left(\mathrm{h}^{2}\right)$ of linoleic acid was determined using the offspring-midparent regression for the $\mathrm{M}_{2}$ and $\mathrm{M}_{5}$ populations. The values of the regression coefficients were 0.14 and 0.12 respectively (IV). The value of the realized heritability $(\mathrm{R} / \mathrm{S})$, in which the total amount of the selection performed is included, was $0.11(\mathrm{~V})$.

The variance of linoleic acid was found to decrease in comparison to that for the controls during the course of the selection process. The changes in the coefficient of variation (C.V.) indicated a similar trend (V).

The $\alpha$-linolenic acid content had increased significantly with respect to that for the controls within two generations $\left(\mathrm{M}_{4}, \mathrm{M}_{7}\right)(\mathrm{V})$. The increase in the linoleic acid content brought about through selection caused an opposite effect on the oleic acid level. On the other hand, the trend in the case of the $\alpha$-lino- lenic acid level, starting from the $\mathrm{M}_{5}$ progeny, was opposite to that for linoleic acid. Exceptions in the case of saturated fatty acids were also found, the palmitic acid content showing an increasing trend as the levels for other components fell (V).

Erucic acid occurred on the average at a concentration of $0.1 \%$ per generation throughout the duration of the breeding programme (V).

Finally, the yield was determined on the breeding lines showing the highest linoleic acid content. The fatty acid composition, crude fat content and oil yield of the material obtained from replicate block experiments were compared to the corresponding values for controls and summer turnip rape varieties commonly cultivated in Finland (VII). The lines with the best linoleic acid contents and oil yields are presented in Table 7.

The lines with the highest linoleic acid contents (97703 and 97712) proved to have an oil yield comparable to that of the 'Emma' variety in yield trials carried out in two successive years. The crude fat content of the bred material was c. $2 \%$-units higher than that of the standard varieties. Line 97711 promises to give a very high oil yield. Most of the linoleic acid lines were erucic acid-free and, in addition, the $\alpha$-linolenic acid level did not significantly differ from that of the controls (VII).

Table 7. Quality characteristics of summer turnip rape varieties and the control and selected lines in Trial 1984 $(\mathrm{N}=3)$.

\begin{tabular}{|c|c|c|c|c|c|c|}
\hline \multirow[t]{2}{*}{ Material } & \multicolumn{3}{|c|}{ Fatty acids $(\%)$} & \multirow{2}{*}{$\begin{array}{l}\text { Seed yield } \\
\text { (rel.) }\end{array}$} & \multirow{2}{*}{$\begin{array}{c}\text { Crude fat } \\
(\%)\end{array}$} & \multirow{2}{*}{$\begin{array}{l}\text { Oil yield } \\
\text { (rel.) }\end{array}$} \\
\hline & $18: 2 \omega 6$ & $18: 3 \omega 3$ & $22: 1 \omega^{2} 9$ & & & \\
\hline \multicolumn{7}{|l|}{ Varieties } \\
\hline Ante & 21.2 & 10.8 & 0.6 & 86 & 43.8 & 82 \\
\hline Emma & 22.4 & 11.4 & 0.5 & 117 & 44.6 & 113 \\
\hline Controls & 22.4 & 12.1 & - & 100 & 46.1 & 100 \\
\hline \multicolumn{7}{|l|}{ Selection } \\
\hline Hјa 97815 & 25.5 & 11.8 & - & 103 & 46.6 & 104 \\
\hline 97712 & 25.2 & 12.1 & - & 115 & 46.4 & 116 \\
\hline 97703 & 25.2 & 12.2 & - & 110 & 45.7 & 109 \\
\hline 97832 & 24.3 & 12.3 & - & 114 & 47.0 & 116 \\
\hline 97824 & 24.3 & 12.6 & - & 124 & 46.2 & 125 \\
\hline 97711 & 23.6 & 11.8 & 0.9 & 133 & 46.5 & 139 \\
\hline 97828 & 23.5 & 12.3 & - & 124 & 46.6 & 126 \\
\hline
\end{tabular}




\section{Interrelationships between fatty acids}

The saturated fatty acids - stearic (18:0) and arachidic acids (20:0) - were positively correlated $(\mathrm{P}<0.001)$ with each other, as was also the case with arachidic and behenic acids (22:0). Oleic acid was positively correlated $(\mathrm{P}<0.001)$ with stearic acid, and negatively correlated $(\mathrm{P}<0.001)$ with linoleic acid $(\mathrm{VI})$. The correlation between linoleic and $\alpha$-linolenic acids remained positive $(r=0.07-0.44)$ in all the generations, and in most cases was statistically significant. Significant negative correlations were also found between these compounds both in some individual yields (VI) and within some families in the material cultivated in the field (V).
The correlation between linoleic and $\alpha$ linolenic acids was also calculated on individuals selected as parents and on their progeny. In the material cultivated in the field, in particular, the correlations were found to be of the same order of magnitude (V).

The interrelationships between the $1 \omega 9$ fatty acids and their corresponding $1 \omega 7$ isomers were studied in material containing different levels of erucic acid $(0.3-37 \%)$. The $1 \omega 7$ isomers (18: $1 \omega 7,20: 1 \omega 7$ and 22:1 $1 \omega 7)$ were found to be intercorrelated $(\mathrm{P}<0.001)$, similarly as was the case between the $1 \omega 9$ isomers. The correlation between the two fatty acid series $(1 \omega 9$ and $1 \omega 7)$ was positive and highly significant (III). 


\section{Discussion}

\section{A. Comparison of sampling techniques in fatty acid analysis}

The use of capillary columns in analytical gas chromatography has rapidly become widespread during the past decade. Considerably higher resolution can be obtained in comparison to packed columns, and it has been possible to shorten the analysis time without any loss in resolution. The detection of compounds in ever smaller amounts has also become possible in trace-component analysis. However, the small diameter of the column means that the capacity of the column is reduced and special injection systems are needed. The traditional split and splitless injection techniques have been the object of considerable criticism owing to their inadequate precision in quantitative work (SсномBURG et al. 1977, Grob and Grob 1979, Grob and Neukom 1979, Schomburg 1979, Munari and Trestianu 1981). Traditional sample-injection techniques were compared with new injection methods in the study in hand. In addition, the magnitude of the analytical error in the GC process and the suitability of the various methods from the point of view of fatty-acid breeding work were examined (I, III, V).

The split technique, which is the method most commonly used for routine work, proved to be rather unreliable in the analysis of fatty acids. The effects of sample size and the split ratio on the quantitative results were especially pronounced when low levels of erucic acid were being determined. It was not possible to analyse, even with carefully optimized split and splitless injection, the erucic acid levels attainable with the on-column method (I). Taking the precision level of below $1 \%$ (C.V.) proposed by YANG et al. (1978) as the criterion, the split method has given a degree of precision of this magnitude for only 3 of the main components $(>10 \%)$ (I, III).

The mean precision of the on-column technique $(\mathrm{C} . \mathrm{V} .=2.3 \%)$ was clearly better than that of the conventional split method (C.V. $=5.7 \%$ and $6.4 \%$ ) (Table 3). The CV values for compounds present at levels of below $1 \%$ have decreased considerably (Table $1, \mathrm{I})$, and are in good agreement with the precision level obtained by BADINGS and de JONG (1983) and GeEraert et al. (1983) in their fatty acid analyses (Table 1). The superiority of this technique in comparison to traditional sample injection methods has been demonstrated in a large number of studies during the past few years (e.g. Grob and Neukom 1980, Schomburg et al. 1981, Munari and TresTIANU 1981).

Despite the good precision and accuracy of the on-column method, its applicability is restricted by the unvolatilized impurities that accumulate at the column inlet and subsequently bring about a reduction in the resolution (Schomburg et al. 1977, Bayer and LiU 1983). The solvent in on-column injection has also been found to sometimes produce peak broadening and thus reduce the resolution (Grob 1982, SANDRA et al. 1983). Introducing the sample with an extremely thin needle is further considered to be a drawback (Poy et al. 1981). The on-column technique is preferred when there is no need for automation 
of the analyses (Venema 1983).

The precision (mean C.V. $=2.0 \%$ and $1.9 \%$ ) of the PTV solvent split technique was found to be of the same order of magnitude as that for the on-column technique (mean C.V. $=2.3 \%$ ) (Tables 3 and 5). The results also show that the variation caused by the derivatization method is insignificant compared to the gas chromatographic error (Table 5). The precision (C.V. $=0.1-0.2 \%$ ) of the main components $(10 \%)$ is in good agreement with values obtained with on-column or "solvent-free» injection (GEeRAERT et al. 1983, Caplan and Cronin 1983) (Table 1). Earlier analyses carried out using PTV showed that the splitless technique has the best precision, and that the split method gives the most accurate results compared to on-column injection (LAaKso et al. 1983). Schomburg et al. (1983 a, $1983 \mathrm{~b})$ have also found that temperature programmed (TP) injection carried out using the splitless or split method does not cause any marked discrimination. Using the PTV method in place of the on-column method has proved to be very suitable for, e.g. chemotaxonomic studies on volatile oils (HoLOPAINEN et al. 1983). Detailed comparison of the sampling methods showed that a high injection temperature resulted in a many times greater analytical error, especially in the case of volatile monoterpenes (HILTUNEN et al. 1983 a). The headspace technique also gives better precision than manual hot injection for these components (HiltunEN et al. 1983 b).

When the proportion of the analysis error was compared to the fatty acid variation in turnip rape, values of over $99 \%$ were obtained for the variation of a number of components with the PTV technique (VI). The good separation of the components is illustrated by the determination of vaccenic acid with a precision of $4 \%$ (C.V.) even, using a column only $15 \mathrm{~m}$ long (VI). Separation is presumably improved by the fact that there is a greater difference between the volatilization instant of the solvent and that of the fatty acids in temperature-programmed injection than in hot injection.
The advantages of the temperature-programmed injection technique in gas chromatographic analysis are considered to be so clear that it will presumably replace the classical split and splitless hot injection methods (Grob 1984). In this study, the PTV technique was found to be even more suitable than the on-column method as far as the studied fatty acids were concerned. Impurities in the sample are not as critical a factor as in oncolumn injection, analysis on short columns even gave good separation and, in addition, it is possible to automate the method.

\section{B. Selection for higher linoleic acid content in rapeseed oil}

As was the case in the breeding of erucic acid-free varieties, the half-seed technique is considered to be the best method for further modifying the proportions of different fatty acids. Only a relatively small amount of material is required, crossings can be done between known chemotypes, and cultivation in the greenhouse makes the breeding work independent of the season. Even a 5 to $6 \%$-unit increase in the linoleic acid content has been achieved through a single crossing (JönssON 1977 a). However, the linoleic acid level of the common summer turnip rape varieties is still only about $22 \%$ (Canadian "Canola» type oil) (DAUN 1983).

A phenotypic selection for single plants best suited for cultivation under field conditions was carried out in this study on summer turnip rape. The individuals with the highest linoleic acid content were selected for further breeding on the basis of the fatty acid composition of their yields, and the lines finally obtained were culled on the basis of their yield (II, IV, V, VII).

The fatty acid variation of the main components under field conditions was rather constant during successive years, the relative standard deviation (C.V.) usually being under $10 \%(\mathrm{~V})$. On the other hand, the enyironment had a considerable effect under greenhouse conditions. The linoleic, and especially the $\alpha$ - 
linolenic acid content, tended to increase and almost double values were found in the variances. Neither was it possible to show the effect of selection on the linoleic acid content (IV, V, VI). Although it is impossible to carry out exact comparison between the greenhouse conditions, the result goes against the belief concerning the better suitability of greenhouse conditions in breeding work (JönsSON 1975 a, THIES 1971). The clearer effect of the environment on $\alpha$-linolenic than linoleic acid agrees with the results obtained by Jönson (1975 a) in breeding experiments with turnip rape. As the individual plant selection on linoleic acid content was effective only in the material grown in the field (V), it would indicate that a more reliable selection can also be made on single seeds from such material.

The only increase which systematically followed that of the linoleic acid content under field conditions was in the level of eicosadienoic acid $(20: 2 \omega 6)$ (II, V). This compound is an expected elongation product of linoleic acid (Stearns 1970). However, the analytical error was rather large when determining the variation of this component (III). Higher contents $(0.3-0.6 \%)$ have usually been obtained with high erucic-acid varieties (ACKMAN 1966) and elevated values occasionally occurred also in the present material when the distributions of eicosenoic and eicosadienoic acid were studied (II). This may mean that eicosenoic acid $(20: 1 \omega 9)$ is also a precursor for eicosadienoic acid. The close dependance between $1 \omega 7$ isomers of $C_{18}-C_{22}$ fatty acids, indicated by highly significant correlations, as was also the case between corresponding $1 \omega 9$ ،isomers (III), would support the hypothesis of APPELQVIST (1968) that elongation of these isomer series takes place in parallel under the control of a single gene system.

The breeding trials carried out in the field demonstrated that the linoleic acid content can be increased, using individual plant selection, without affecting the $\alpha$-linolenic acid content (V). It was possible, following the field trials, to select erucic acid-free lines with elevated linoleic acid contents that had yields which were fully comparable to the varieties presently cultivated in Finland (VII).

The effect of selection on the linoleic acid level during eight generations was very small $(22 \rightarrow 25 \%)$. This corresponds well to the realized heritability of $0.11\left(h^{2}=b=R / S\right)$ obtained in the study (V). However, it is a specific estimate for the varieties and is highly dependent on the method of breeding (SIMMONDS 1979). A low value is to be expected when breeding polyunsaturated fatty acids of turnip rape under uncontrolled crossing conditions (JöNSSON 1975 a). Individual selection with respect to the oil content has also given corresponding heritability values (KRZYMANSKI 1983).

The response to selection for linoleic acid varied considerably during the course of the breeding work (V). When the analytical precision of fatty acids and environmental conditions are the same for the selection lines and controls, as can be assumed to be the case here, the selection intensity is one of the most important factors affecting the response (FALCONER 1981). The proportion of selected individuals out of the basic population varied between 9 to $32 \%$, the selection of the $M_{7}$ generation $(9 \%)$, for instance, having the greatest intensity and also giving the greatest difference in linoleic acid content with respect to the controls $(3.7 \%)(\mathrm{V})$. Increasing the response by means of high selection intensity is, however, complicated because the variance is expected to decrease as a result of directional selection, and hence the genetic base will also narrow (FALCONER 1981). Repeated irradiation may be one possible means of again increasing the genetic variability of linoleic acid in the breeding material after its variation has already fallen to the level of the controls (V).

One interesting feature was the change in the response of $\alpha$-linolenic acid as opposed to that of linoleic acid (V). The fact that the partial independence of these two components, which is supported by studies on both their composition and biosynthesis (RAKOw 1973, BRAR and THIEs 1978), does not appear until in field conditions, would indicate that the 
individual selection made on greenhouse material is also ineffective when a high linoleic/ $\alpha$-linolenic acid ratio is being aimed for. JónsSON (1975 a) has found that the corresponding independence between these compounds in turnip rape is variety dependent. The correlations between linoleic and $\alpha$ linolenic acids in the parents and their progenies corresponded rather well with each other during the breeding period (V). Therefore, taking the $\alpha$-linolenic acid content also into account may probably be advantageous in modifying the fatty acid ratio, despite the fact that no rapid results can be expected by simultaneous selection (RöbBELEN and NITSCH 1975). However, due to the new evidence for the role of $\alpha$-linolenic acid the balance between linoleic and $\alpha$-linolenic acids probably should not be too radically altered (ACKMAN 1983).

The results of this study show that selection for higher linoleic acid content can form part of breeding work designed to produce goodyielding summer turnip rape varieties adapted to Finnish field conditions. The improved analytical techniques permit more accurate con- trol of the erucic acid levels, as well as improving the reliability of selection in modifying the polyunsaturated fatty acid composition in rapeseed oil. Furthermore, it may be possible to achieve a greater elevation in the linoleic/ $\alpha$-linolenic acid ratio by more effective exploitation of extreme chemotypes.

Despite the low content of polyunsaturated fatty acids, rapeseed oil has been shown to have an appreciable effect on serum lipid patterns, lowering the cholesterol level, in particular. (McDonald 1983, SAvore et al. 1983). Furthermore, $\alpha$-linolenic acid is considered to be responsible for increasing the content of eicosapentaenoic acid (EPA) (LASSERE and JАСОтот 1983). As these constituents have been one of the foremost questions in studying the risk factors of coronary heart disease in Finnish populations (MiETtINEN et al. 1982, VARTIAINEN et al. 1984), determining the role of rapeseed oil in our diet is of prime importance. Rapeseed oil is, in respect to linoleic and $\alpha$-linolenic acid, an exeptionally balanced vegetable oil, which must be considered as a serious alternative among sources of essential fatty acids. 


\section{References}

ACKmAn, R.G. 1966. Analysis of the monoethylenic fatty acids of rapeseed by open tubular gas chromatography. J. Am. Oil Chem. Soc. 43: 483-486.

-, Hooper, S.N. \& Hingley, J. 1971. Monoethylenic fatty acids of a partially hydrogenated herring oil. J. Am. Oil Chem. Soc. 48: 804-806.

-, Barlow, S.M. \& Duthie, I.F. 1977. Erucic acid in edible fats and oils: a collaborative study on determination by open-tubular (capillary) gas-liquid chromatography. J. Chromatogr. Sci. 21: 87-93.

- \&Sebedio, J.-L. 1978. The minor fatty acids of rapeseed oil. Proc. $5^{\text {th }}$ Int. Rapeseed Conf., Malmö, Sweden, F: 9-12.

-, 1983. "Chemical Composition of Rapeseed Oil" in Kramer, Sauer \& Pigden, High and Low Erucic Rapeseed Oils. Academic Press, 582 p. Toronto-New York-London.

ANON. 1978. Laki kotimaisen öljykasvituotannon edistămisestä. Suomen Asetusk. n:o 262.

$\ldots, 1980$. Commission directive of 25 July, 1980 relating to the Community method of analysis for determining the erucic acid content in oils and fats intended to be used as such for human consumption and foodstuffs containing added oils or fats, (80/89/EEC). Offical Journal of the European Communities L 254: 35-41.

—, 1981. Kasviöljyt. Margariiniteollisuuden tiedotuskeskus. 16 p.

-, 1982. Laki kotimaisesta öljykasvituotannosta. Suomen Säädösk. n:o 965.

APpelqvist, L-Å. 1968. Lipid patterns in Cruciferae. Acta Univ. Lund. Sectio II, No. 7: 1-25.

—, 1972. "Chemical Constituents of Rapeseed" in Appelqvist \& Ohlson, Rapeseed: cultivation, composition, processing and utilization. Elsevier, $391 \mathrm{p}$. Amsterdam-London-New York.

Arrendale, R.F., Chapman, G.W. \& Chortyk, O.T. 1983. Gas chromatographic analyses of fatty acids on laboratory-prepared fused silica Silar 10C capillary columns. J. Agric. Food Chem. 31: 1338-1342.

Badings, H.T. \& De Jong, C. 1983. Glass capillary gas chromatography of fatty acid methyl esters. A study of conditions for the quantitative analysis of shortand long-chain fatty acids in lipids. J. Chromatogr. 279: 493-506.
BARTKOWIAK-Broda, I. 1978. Inheritance of fat content and fatty acid composition in seeds of zero-erucic winter rape (B. napus). Proc. $5^{\text {th }}$ Int. Rapeseed Conf., Malmö, Sweden, B: 119-123.

- \& Krzymanski, J. 1983. Inheritance of C-18 fatty acids composition in seed oil zeroerucic winter rape Brassica napus L. Proc. $6^{\text {th }}$ Int. Rapeseed Conf., Paris, France, G: $477-482$.

Bayer, E. \& Liv, G.H. 1983. New split injection technique in capillary column gas chromatography. $\mathrm{J}$. Chromatogr. 256: 201-212.

Bengtsson, L., v.Hofsten, A. \& Loof, B. 1972. "Botany of Rapeseed" in Appelqvist \& Ohlson, Rapeseed: cultivation, composition, processing and utilization. Elsevier, 391 p. Amsterdam-London-New York.

Bohov, P., Baláz, V. \& HrivŇá, J. 1984. Analysis of fatty acid methyl esters on an SP 2340 glass capillary column. J. Chromatogr. 286: 247-252.

Brar, G.S. \& Thies, W. 1978. Biosynthesis of $\alpha$-linolenic acid in leaves and seeds of rape (Brassica napus L.) Proc. $5^{\text {th }}$ Int. Rapeseed Conf., Malmö, Sweden, F: $27-30$.

Budowski, P., Trostler, N., Lupo, M., Vaisman, N. \& ELDOR, A. 1984. Effect of linseed oil ingestion on plasma lipid fatty acid composition and platelet aggregability in healthy volunteers. Nutr. Res. 4: $343-346$

CAPLAN, P.J. \& Cronin, D.A. 1983. Simple device for solvent-free injection of high-boiling compounds in capillary gas chromatography. J. Chromatogr. 267: 19-28.

Craig, B.M. \& Wetter, L.R. 1959. Varietal and environmental effects on rapeseed. II. Fatty acid composition of the oil. Can. J. Plant Sci. 39: 437-442.

-, 1961. Varietal and environmental effects on rapeseed. III. Fatty acid composition of 1958 varietal tests. Can. J. Plant Sci. 41: 204-210.

DAUN, J.K. 1983. "The Introduction of Low Erucic Acid Rapeseed Varieties into Canadian Production» in Kramer, Sauer \& Pigden, High and Low Erucic Rapeseed Oils. Academic Press, 582 p. Toronto-New YorkLondon.

Downey, R.K. \& HaRveY, B.L. 1963. Methods of breeding for oil quality in rape. Can. J. Plant Sci. 43: 271-275. 
-, 1964. A selection of Brassica campestris L. containing no erucic acid in its seed oil. Can. J. Plant Sci. 44: 295 .

- \& Craig, B.M. 1964. Genetic control of fatty acid biosynthesis in rapeseed (Brassica napus L.) J. Am. Oil Chem. Soc. 41: 475-478.

- \& McGregor, D.I. 1975. Breeding for modified fatty acid compostion. Adv. Plant Sci. 12: 151-167.

,- 1978 . Breeding for quality. Proc. $5^{\text {th }}$ Int. Rapeseed Conf., Malmő, Sweden, B: 106-112.

- , 1983. "The Origin and Description of the Brassica Oilseed Crops" in Kramer, Sauer \& Pigden, High and Low Erucic Rapeseed Oils. Academic Press, 582 p. Toronto-New York-London.

Dyerberg, J., Bang, H.O., Stoffersen, E., Moncada, S. \& V VANE, J.R. 1978. Eicosapentaenoic acid and prevention of thrombosis and atherosclerosis? Lancet, ii: $117-119$.

EHRENDORFER, 1983. "Evolution und Systematik" in Strasburgers Lehrbuch der Botanik (v. Denffer, Ziegler, Ehrendorfer \& Bresinsky). Gustav Fischer Verlag. 32. Aufl. 1161 p. Stuttgart-New York.

FALCONER, D.S. 1981. Introduction to Quantitative Genetics, 2nd ed. Longman Group Ltd. 340 p. LondonNew York.

Fochem, H. 1985. Der Weltmarkt der Pflanzenöle, ihre Produktion, Verwendung und Vermarktung. FetteSeifen-Anstrichmittel 87(2): 47-52.

Fondu, M. 1979. Chemistry of dietary oils and fats. Acta Cardiolog. Suppl. XXIII: 74-94.

Frohne, D. \& Jensen, U. 1985. Systematik des Pflanzenreichs. 3. Aufl. Gustav Fischer Verlag. 355 p. Stuttgart-New York.

Galli, M. \& Trestianu, S. 1981. Benefits of a special cooling system to improve precision and accuracy in non-vaporizing on-column injection procedures. J. Chromatogr. 203: 193-205.

GANDER, K-F. 1984. Die Fettversorgung des Menschen aus wirtschaftlicher und technologischer Sicht. FetteSeifen-Anstrichmittel 86(1): 1-8.

Geeraert, E., Sandra, P. \& De Schepper, R. 1983. Oncolumn injection in the capillary gas chromatographic analysis of fats and oils. J. Chromatogr. 279: $287-295$.

Golovnya, R.V., Kuzmenko, T.E. \& Vasilev, A.V. 1984. Stable and reproducible selective glass capillary columns with polysiloxane stationary phases for the analysis of fatty acid methyl esters. J. Chromatogr. 292: 49-55.

Grice, H.C. \& Heggtveit, H.A. 1983. "The Relevance to Humans of Myocardial Lesions Induced in Rats by Marine and Rapeseed Oils» in Kramer, Sauer \& Pigden, High and Low Erucic Rapeseed Oils. Academic Press, 582 P. Toronto-New York-London.

Groв, K. \& Groв, G. 1976. A new, generally applicable procedure for the preparation of glass capillary columns. J. Chromatogr. 125: 471-485.
-, 1978. On-column injection onto capillary columns. Part 2: Study of sampling conditions; practical recommendations. J. High Resolut. Chromatogr. \& Chromatogr. Comm. 1: 263-267.

- \& Grob, K. Jr. 1978. On-column injection on to capillary columns. J. Chromatogr. 151: 311-320.

— \& GRов, G. 1979. Practical capillary gas chromatography - a systematic approach. J. High Resolut. Chromatogr. \& Chromatogr. Comm. 2: 109-117.

Grob, K. Jr. \& Neukom, H.P. 1979. The influence of the syringe needle on the precision and accuracy of vaporizing GC injections. J. High Resolut. Chromatogr. \& Chromatogr. Comm. 2: 15-21.

- \& Neukom, H.P. 1980. Factors affecting the accuracy and precision of cold on-column injections in capillary gas chromatography. J. Chromatogr. 189: 109-107.

- , 1981. Peak broadening or splitting caused by solvent flooding after splitless or cold on-column injection in capillary gas chromatography. J. Chromatogr. 213: 3-14.

- , 1984. Movements of the sample plug in the column inlet after on-column injection in capillary gas chromatography. J. Chromatogr. 283: 21-35.

HAKEN, J.K. 1984. Developments in polysiloxane stationary phases in gas chromatography. J. Chromatogr. Chromatogr. Rev. 300: 1-77.

Hamilton, D.V., Lea, E.J.A. \& Jones, S.P. 1980. Dietary fatty acids and ischaemic heart disease. Acta Med. Scand. 208: 337-340.

Harvey, B.L. \& Downey, R.K. 1964. The inheritance of erucic acid content in rapeseed (Brassica napus). Can J. Plant Sci. 44: 104-111.

Haug, M., Dieterich, I., Laubach, C., Reinhardt, D. \& HARZER, G. 1983. Capillary gas chromatography of fatty acid methyl esters from human milk lipid subclasses. J. Chromatogr. 279: 549-553.

HaY, C.R.M., Durber, A.P. \& Saynor, R. 1982. Effect of fish oil on platelet kinetics in patients with ischaemic heart disease. Lancet i: 1269-1272.

Heckers, H., Melcher, F.W. \& Schloeder, U. 1977. SP 2340 in the glass capillary chromatography of fatty acid methyl esters. J. Chromatogr. 136: 311-317.

Hiltunen, R., Huhtikangas, A. \& Hovinen, S. 1979. Breeding of a zero erucic spring turnip-rape cultivar, Brassica campestris L., adapted to Finnish climatic conditions. I. The use of glass capillary column gas chromatography in fatty acid analysis. Acta Pharm. Fenn. 88: 31-34.

-, Laakso, I., Hovinen, S. \& Derome, J. 1982. Sampling techniques in the glass capillary gas chromatography of fatty acids of rape-seed. J. Chromatogr. 237: $41-48$.

-, Holopainen, M., Laakso, I. \& v.Schantz, M. 1983 a. Comparison between a programmed temperature vaporizer (PTV) and other sampling techniqueś in the GLC-analysis of volatile oils. Acta Pharm. 
Fenn. 92: 197-201.

-, LAakso, I. \& Scheffer, J.J.C. 1983 b. Application of headspace gas chromatography in essential oil analysis. I. Precision. Acta Pharm. Fenn. 92: 209-21.

Holopainen, M., Hiltunen, R., Forsen, K. \& v. Schantz, M. 1983. Comparisons between steam-distillation and extraction in the analysis of tansy oil (Tanacetum vulgare L.) for chemotaxonomic studies. Acta Pharm. Fenn. 92: 203-208.

Holman, R.T. 1970. Biological activities of and requirements for polyunsaturated acids. Prog. Chem. Fats 9: $611-682$.

Horrobin, D.F. 1982. "Essential Fatty Acids: A Review» in Horrobin, Clinical Uses of Essential Fatty Acids. Eden Press, 214 p. Montréal-London.

Hougen, F.W. \& Wasowicz, E.W. 1978. Isomeric monounsaturated fatty acids in edible fats and oils with reference to myocardial lesions in animals. Proc. 5th Int. Rapeseed Conf., Malmö, Sweden, F: 13-15.

Hovinen, S. 1985. „Öljykasvit». Siemenjulkaisu. Hankkijan Kasvinjalostuslaitos. 188 p.

Jaeger, H., Klor, H-U., Blos, G. \& Ditschuneit, H. 1975. Reliable separation of cis and trans fatty acids by gas liquid chromatography on glass capillary columns. Chromatographia 8(9): 507-510.

Johansson, S-Å. \& Uppstrom, B. 1978. Analys av oljeväxtfrö: Bestämning av fettsyrasammansăttning. Sver. Utsädesför. Tidskr. 88: 35-44.

Jonsson, R. 1973. Breeding for low erucic acid content in summer turnip rape (Brassica campestris L. var. annua L.). Z. Pflanzenzüchtg. 69: 1-18.

—, 1975 a. Forrädling för förbăttrad fettsyrasammansăttning i oljevăxter. III. Höjd linolsyrahalt i vårrybs (Brassica campestris L. var. annua L.). Sver. Utsädesför. Tidskr. 85: 19-29.

—, 1975 b. Gulfröighet i raps och rybs. II. Växtförädling för forbăttrad olje- och mjölkvalitet i gulfröigt material. Sver. Utsădesfor. Tidskr. 85: 271-278.

-, 1977 a. Erucic-acid heredity in rapeseed (Brassica napus L. and Brassica campestris L.). Hereditas 86: 159-170.

-, $1977 \mathrm{~b}$. Breeding for improved oil and meal quality in rape (Brassica napus L.) and turnip rape (Brassica campestris L.). Hereditas 87: 205-218.

— \& Persson, C. 1983. Breeding for improved fatty acid composition in rapeseed. Proc. 6th Int. Rapeseed Conf., Paris, France, C: $311-314$.

Kaitaranta, J. 1981. Fish roe lipids and lipid hydrolysis in processed roe of certain Salmonidae fish as studied by novel chromatographic techniques. Research Reports $14 / 1981$, p. $31+$ app. p. 49 , Techn. Res. Centre of Finland.

Kondra, Z.P. \& Thomas, P.M. 1975. Inheritance of oleic, linoleic and linolenic acids in seed oil of rapeseed (Brassica napus). Can. J. Plant Sci. 55: 205-210.

- \&WILson, T.W. 1976. Selection for oleic, linoleic and linolenic acid content in $\mathrm{F}_{2}$ populations of rape. Can.
J. Plant Sci. 56: $961-966$.

Krzymánskı, J. 1984. Possibilities of breeding for higher oil and protein contents in winter rape seeds. FetteSeifen-Anstrichmittel 86(12): 468-470.

Laakso, I., Holopainen, M., Hiltunen, R. \& v. Schantz, M. 1983. Application of a programmed temperature vaporizer (PTV) in the gas chromatographic analysis of volatile oils and fatty acids. Abstr. ler Gesamtkongr. Pharm. Wissensch., München, GFR, 296297.

-, Hiltunen, R., Koiranen, P. \& Seppänen, T. \& v. SChantZ, M., 1984. Vegetable seed and fish oils as a source of polyunsaturated fatty acids (PUFA) of the $\omega 6$ and $\omega 3$ series. Farm. Tijdschr. Belg. 61(3): $373-374$.

Lanza, E. \& Slover, H.T. 1981. The use of SP 2340 glass capillary columns for the estimation of trans fatty acid content of foods. Lipids 16(4): 260-267.

LASSERE, M. \& JACOTOT, B. 1983. Effects á long terme de plusieurs graisses alimentaires (dont l'huile de colza) sur les lipides sériques d'une population de religieuses bénédictines. Proc. 6th Int. Rapeseed Conf., Paris, France, K: 1653-1659.

LeE, M.L. \& W capillary columns for gas chromatography. J. Chromatogr. Rev. 184: 235-312.

LERCKER, G. 1983. Short capillary columns in the analysis of lipids. J. Chromatogr. 279: 543-548.

LOOF, B. \& APPELQvist, L-Ȧ. 1972. "Plant Breeding for Improved Yield and Quality" in Appelqvist \& Ohlson, Rapeseed: cultivation, composition, processing and utilization. Elsevier, 391 p. Amsterdam-London-New York.

LIE KEN JIE, M.S.F. 1980. The characterization of longchain fatty acids and their derivatives by chromatography. Adv. Chromatogr. 18: 1-57.

Masson, L. 1981. Relative nutritional value of various dietary fats and oils. J. Am. Oil. Chem. Soc. 58(3): 249-255.

McDonald, B.E. 1983. "Studies with High and Low Erucic Acid Rapeseed Oil in Man» in Kramer, Sauer \& Pigden, High and Low Erucic Rapeseed Oils. Academic Press, 582 p. Toronto-New York-London.

Metcalfe, L.D. \& WANG, C.N. 1981. Rapid preparation of fatty acid methyl esters using organic base-catalyzed transesterification. J. Chromatogr. Sci. 19: 530-535.

Miettinen, T.A., Naukkarinen, V., Huttunen, J.K., Mattila, S. \& Kumlin, T. 1982. Fatty-acid composition of serum lipids predicts myocardial infarction. Br. Med. J. 285: 993-996.

-, Alfthan, G., Huttunen, J.K. Pikgarainen, J., Naukkarinen, V., Mattila, S. \& Kumlin, T. 1983. Serum selenium concentration related to myocardial infarction and fatty acid content of serum lipids. $\mathrm{Br}$. Med. J. 287: 517-519.

Munari, F. \& Trestianu, S. 1981. Comparison of some quantitative results obtained with non-vaporizing cold 
on-column and vaporizing split-splitless injection techniques. In KaISER (ed.) Proc. 4th Int. Symp. Capillary Chromatography, Hindelang, 349-369.

LOOF, B. 1972. "Cultivation of Rapeseed" in Appelqvist \& Ohlson, Rapeseed: cultivation composition, processing and utilization. Elsevier, 391 p. AmsterdamLondon-New York.

Oster, P. \& SChlierf, G. 1982. Kardiovakuläre Risikofaktoren 1982. Fette-Seifen-Anstrichmittel 84(2): $621-622$.

PAszkowski, W.A. 1983. The Canadian Canola industry. Proc. 6th Int. Rapeseed Conf., Paris, France, A: 3-8.

Penttilä, I., Huhtilingas, A., Herranen, J., Eskelinen, S. \& Mollanen, O. 1984. Simultaneous measurement of free and esterified fatty acids by gas chromatography from normal and type IV hyperlipoproteinaemic sera. Ann. Clin. Res. 16: 13-17.

Pigden, W.J. 1983. "World Production and Trade of Rapeseed and Rapeseed Products" in Kramer, Sauer \& Pigden, High and Low Erucic Rapeseed Oils, Academic Press, 582 p. Toronto-New York-London.

Poy, F., Visani, S. \& Terrosi, F. 1981. Automatic injection in high-resolution gas chromatography: A programmed temperature vaporizer as a general purpose injection system. J. Chromatogr. 217: 81-90.

,- 1982 . A new temperature programmed injection technique for capillary GC: Split mode with cold introduction and temperature programined vaporization. Chromatographia 16: 345-348.

RAKow, G. 1973. Selektion auf Linol- und Linolensäuregehalt in Rapssamen nach mutagener Behandlung. Z. Pflanzenzüchtg. 69: 62-82.

Robbelen, G. \& Nitsch, A. 1975. Genetical and physiological investigations on mutants for polyenoic fatty acids in rapeseed, Brassica napus L. I. Selection and description of new mutants. Z. Pflanzenzüchtg. 75(2): 93-105.

-, 1976. Züchtung und Erzeugung von Quaitätsraps in Europa. Fette-Seifen-Anstrichmittel 78(1): 10-17.

-, 1983. Fortschritte in der Welterzeugung von Rapssaaten. Fette-Seifen-Anstrichmittel 85(10): 395-398.

SAnders, T.A.B. \& Younger, K.M. 1983. The effect of dietary supplements of $\omega 3$-polyunsaturated fatty acids on the fatty acid composition of platelets and plasma choline phosphoglycerides. Br. J. Nutr. 45: 613-616.

Sandra, P., v. Roelenbosch, M., Verzele, M. \& Bicchi, C. 1983. Experiments with cold on-column injection. J. Chromatogr. 279: 279-286.

Savoie, L., Navratil, O., Moorjani, S. \& Lupien, P.J. 1983. Effects comparatifs de l'huile de tournesol et de l'huile de colza à faible teneur en acide érucic dans le traitement de l'hypercholestérolémie familiale hétérozygote. Proc. 6th. Int. Rapeseed Conf., Paris, France, K: 1700-1705.

Schomburg, G. \& Husmann, H. 1975. Methods and techniques of gas chromatography with glass capillary columns. Chromatographia 8(9): 517-530.
-, Behlau, H., Dielmann, R., Weeke, F. \& Husmann, H. 1977. Sampling techniques in capillary gas chromatograhy. J. Chromatogr. 142: 87-102.

- , 1979. Practical limitations of capillary gas chromatography. J. High Resolut. Chromatogr. \& Chromatogr. Comm. 2: 461-474.

-, Husmann, H. \& Rittman, R. 1981. "Direct” (oncolumn) sampling into glass capillary columns. Comparative investigations on split, splitless and on-column sampling. J. Chromatogr. 204: 85-96.

-, Husmann, H., Behlau, H. \& Schulz, F. 1983 a. Cold sample injection with either the split or splitless mode of temperature-programmed sample transfer. Design and testing of a new, electrically heated construction for universal application of different modes of sampling. J. Chromatogr. 279: 251-258.

-, Husmann, H., Schulz, F., Teller, G. \& Bender, M. 1983 b. Cold sample injection with either the split or splitless mode of temperature-programmed sample transfer. Comparison to cold on-column injection with a commercial device. J. Chromatogr. 279: 259-267.

Sebedio, J-L. \& Ackman, R.G. 1979. Some minor fatty acids of rapeseed oils. J. Am. Oil Chem. Soc. 56: $15-21$,

-, FARQUhARSON, T.E. \& ACKMAN, R.G. 1982. Improved methods for the isolation and study of the $\mathrm{C}_{18}, \mathrm{C}_{20}$ and $\mathrm{C}_{22}$ monoethylenic fatty acid isomers of biological samples: $\mathrm{Hg}$ adducts, HPLC, $\mathrm{AgNO}_{3}-\mathrm{TLC} / \mathrm{FID}$, and ozonolysis. Lipids 17(6): 469-475.

Seher, A., Werner, G., Krohn, M. \& Petersen, U. 1979. Ernährungsphysiologische Wirkung erucasăurearmer Rapsöle auf Schweine. 3. Wirkung auf Depotfette und Leberlipide. Fette-Seifen-Anstrichmittel 81(5): 187-192.

Simmonds, N.W. 1979. Principles of Crop Improvement, Longman Group Ltd. 408 p. London-New York.

Sisfontes, L., Nyborg, G., Siensson, L. \& Blomstrand, R. 1981. Separation of complex long chain fatty acid mixtures by high-performance glass capillary gas chromatography. J. Chromatogr. 216: 115-125.

Slover, H.T. \& LANZA, E. 1979. Quantitative analysis of food fatty acids by capillary gas chromatography. J. Am. Oil Chem. Soc. 56: 933-943.

Snedecor, G.W. \& Cochran, W.G. 1967. Statistical Methods, 6th ed. Iowa State University Press, 593 p. Ames, Iowa, USA.

Stage, H. 1982. Physical refining and deodorization of food oils. Fette-Seifen-Anstrichmittel 84(10): 377395.

Stearns, E.M. Jr. 1970. Biosynthesis of unsaturated fatty acids in higher plants. Prog. Chem. Fats 9(4): 453-516.

Stefansson, B.R., Hougen, F.W. \& Downey, R.K. 1961. Note on the isolation of rape plants with seed oil free from erucic acid. Can. J. Plant Sci. 41: 218-219.

— \& Hougen, F.W. 1964. Selection of rape plants (Brassica napus) with seed oil practically free from erucic 
acid. Can. J. Plant Sci. 44: 359-364.

-, 1983. " The Development of Improved Rapeseed Cultivars" in Kramer, Sauer \& Pigden, High and Low Erucic Rapeseed Oils. Academic Press, 582 p. Toronto-New York-London.

Stumpf, P.K. \& Pollard, M.R. 1983. Pathways of fatty acid biosynthesis in higher plants with particular reference to developing rapeseed. ibid.

Svensson, L., Sisfontes, L., Nyborg, G. \& Blomstrand, R. 1982. High performance liquid chromatography and glass capillary gas chromatography of geometric and positional isomers of long chain monounsaturated fatty acids. Lipids 17(1): 50-59.

Thiele, O.W. 1979. Lipide, Isoprenoide mit Steroiden. Georg Thieme Verlag, 415 p. Stuttgart.

Thies, W. 1968. Die Biogenese von Linol- und Linolensäure in den Samen höherer Pflanzen, insbesondere Raps und Rübsen, als Problem der Ölpflanzenzüchtung. Angew. Bot. XLII (3/4): 140-154.

—, 1971. Schnelle und einfache Analysen der Fettsäurezusammensetzung in einzelnen Raps-Kotyledonen. I.
Gaschromatographische und papierchromatographische Methoden. Z. Pflanzenzüchtg. 65(3): $181-202$.

VANE, J.R. \& MoncadA, S. 1979. Polyunsaturated fatty acids as precursors of protaglandins. Acta Cardiol. Suppl. XXIII: $21-37$.

Vartiainen, E., Puska, P., Pietinen, P., Nissinen, A., Leino, U. \& Uusitalo, U. 1984. Ruokavalion vaikutus suomalaisten lasten korkeaan seerumin kolesterolitasoon. Suom. Laaăkäril. 39: 3054-3058.

Venema, A. 1983. Potential of capillary gas chromatography in industrial research laboratories. J. Chromatogr. 279: 103-110.

YanG, F.J. Brown, A.C. \& Cram, S.P. 1978. Splitless sampling for capillary-column gas chromatography. J. Chromatogr. 158: 91-109.

- \& CRAM, S.P. 1979. Characteristics and performance of gas chromatographic detectors with glass capillary columns. J. High Resolut. Chromatogr. \& Chromatogr. Comm. 2: 487-496. 


\section{APPENDIX}

Trivial and systematic names for fatty acids treated in this study are listed below. Omega $(\omega)$ is used to denote the first double bond position in the chain counting from the terminal methyl group.

\begin{tabular}{lll}
\hline Trivial name & Systematic name & Abbreviation \\
\hline palmitic acid & hexadecanoic acid & $16: 0$ \\
stearic acid & octadecanoic acid & $18: 0$ \\
oleic acid & cis-9-octadecenoic acid & $18: 1 \omega 9$ \\
vaccenic acid & cis-11-octadecenoic acid & $18: 1 \omega 7$ \\
linoleic acid & all-cis-9, 12-octadecadienoic acid & $18: 2 \omega 6$ \\
$\gamma$-linolenic acid & all-cis-6, 9, 12-octadecatrienoic acid & $18: 3 \omega 6$ \\
$\alpha$-linolenic acid & all-cis-9, 12, 15-octadecatrienoic acid & $18: 3 \omega 3$ \\
arachidic acid & eicosanoic acid & $20: 0$ \\
eicosenoic acid & cis-11-eicosenoic acid & $20: 1 \omega 9$ \\
& cis-13-eicosenoic acid & $20: 1 \omega 7$ \\
eicosadienoic acid & all-cis-11, 14-eicosadienoic acid & $20: 2 \omega 6$ \\
homo- $\gamma$-linolenic acid & all-cis-8, 11, 14-eicosatrienoic acid & $20: 3 \omega 6$ \\
arachidonic acid & all-cis-5, 8, 11, 14-eicosatetraenoic acid & $20: 4 \omega 6$ \\
eicosapentaenoic acid & all-cis-5, 8, 11, 14, 17-eicosapentaenoic acid & $20: 5 \omega 3$ \\
behenic acid & docosanoic acid & $22: 0$ \\
erucic acid & cis-13-docosenoic acid & $22: 1 \omega 9$ \\
& cis-15-docosenoic acid & $22: 1 \omega 7$ \\
\hline
\end{tabular}




\section{SELOSTUS}

\section{Tutkimus kevätrypsin (Brassica campestris}

\section{L. var. annua) rasvahappojen} analytiikasta ja jalostuksesta

\author{
Into Laakso \\ Helsingin yliopiston farmasian laitos \\ 00170 Helsinki
}

Kotimainen rypsiobljy on viimeisen kymmenen vuoden aikana saanut yhä tärkeämmän aseman elintarviketeollisuuden raaka-aineena. Nykyisistä rypsilajikkeista saatava öljy on varsin kilpailukykyistä, sillă erityisesti erukahappopitoisuuden suhteen laatuvaatimukset meillă ovat varsin tiukat. Viljelyä ei voida kuitenkaan suuressa määrin lisătä, sillä jalostavan teollisuuden mahdollisuudet korvata tuontiöljyjă kotimaisella raaka-aineella ovat suhteellisen rajoitetut johtuen ensisijaisesti rypsiöljyn alhaisesta linolihappopitoisuudesta.

Täman tutkimuksen tarkoituksena oli yksilövalintaa apuna käyttāen kohottaa kevătrypsin siemenöljyn linolihappopitoisuutta sekă tutkia valinnan vaikutuksia rasvahappokoostumukseen ja satoisuuteen. Tutkimuksessa verrattiin edelleen perinteisten ja uusimpien kaasukromatografisten menetelmien luotettavuutta rasvahappoanalytiikassa ja pyrittiin optimoimaan jalostustyőhön parhaiten soveltuva analyysitekniikka.

Jalostuskokeet tehtiin Hankkijan kasvinjalostuslaitoksella Hyrylăssă vuosina 1978 - 85 kanadalaista alkuperăă olevasta kevätrypsiaineistosta. Linolihappolinjojen lopullinen karsinta suoritettiin satoisuuden perusteella.
Vapaapölytteisissă pelto-oloissa tehdyt jalostuskokeet osoittivat, ettă linolihappotasoa on mahdollista kohottaa yksilövalinnalla vaikuttamatta kuitenkaan toisen monityydyttämättömän komponentin, $\alpha$-linoleenihapon, mäăräăn. Parhaat valintalinjat sisaalsivăt linolihappoa n. $25 \%$, minkä lisăksi useat olivat erukahapottomia ja satoisuudeltaan nykyisten lajikkeiden veroisia. Kasvihuoneolosuhteiden todettiin sitävastoin aiheuttavan huomattavaa lisăvaihtelua, eikä valinnan vaikutusta linolihappotasoon voitu osoittaa. Pyrittăessă edelleen kohottamaan rypsioljyn linolihappopitoisuutta saattaisi alhaisen $\alpha$ linoleenihappotason huomioiminen yksilovvalinnassa samanaikaisesti olla merkityksellistă linolihappovalinnan tehostamiseksi.

Alhaisesta monityydyttămăttömien rasvahappojen määrästä huolimatta rypsiöljyllä on todettu olevan varsin edulliset fysiologiset vaikutukset eritoten kolesterolitasoon. Tässă valossa on rypsiöljyă pidettăvă vakavasti otettavana vaihtoehtona välttämättömien rasvahappojen lähteenä, mikä myös tulevaisuudessa on huomioitava rasvahappokoostumusta jalostettaessa. 